\title{
FGF receptor genes and breast cancer susceptibility: results from the Breast Cancer Association Consortium
}

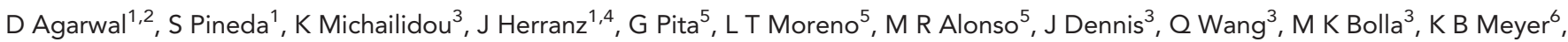
P Menéndez-Rodríguez ${ }^{7}$, D Hardisson ${ }^{8}$, M Mendiola ${ }^{9}$, A González-Neira ${ }^{5}$, A Lindblom ${ }^{10}$, S Margolin ${ }^{11}$, A Swerdlow ${ }^{12,13}$, A Ashworth ${ }^{14}$, $\mathrm{N}$ Orr ${ }^{14}, \mathrm{M}_{\text {Jones }}{ }^{12}, \mathrm{~K}$ Matsuo ${ }^{15}, \mathrm{H}$ Ito ${ }^{16}, \mathrm{H}_{\text {Iwata }}{ }^{17}, \mathrm{~N}$ Kondo ${ }^{17}, \mathrm{kConFab}$ Investigators ${ }^{18}$, Australian Ovarian Cancer Study Group ${ }^{18,19}$, $\mathrm{M} \mathrm{Hartman}^{20}$, M Hui ${ }^{21}$, W Y Lim ${ }^{21}$, P T-C lau ${ }^{22}$, E Sawyer ${ }^{23}$, I Tomlinson ${ }^{24,25}$, M Kerin $^{26}$, N Miller ${ }^{26}$, D Kang ${ }^{27,28}$, J-Y Choi ${ }^{28}$, S K Park ${ }^{27,28}$, D-Y Noh ${ }^{29}$, J L Hopper ${ }^{30}$, D F Schmidt ${ }^{30}$, E Makalic ${ }^{30}$, M C Southey ${ }^{31}, \mathrm{SH} \mathrm{Teo}^{32,33}$, C H Yip ${ }^{33}$, K Sivanandan ${ }^{32}$, W-T Tay ${ }^{34}, \mathrm{H} \mathrm{Brauch}^{35,36}$, T Brüning ${ }^{37}$, U Hamann ${ }^{38}$, The GENICA Network ${ }^{35,36,37,38,39,40,41}$, A M Dunning ${ }^{42}$, M Shah ${ }^{42}$, I L Andrulis ${ }^{43,44}$, J A Knight ${ }^{43,45}$, G Glendon ${ }^{46}$, S Tchatchou ${ }^{43}$, M K Schmidt ${ }^{47}$, A Broeks ${ }^{47}$, E H Rosenberg ${ }^{47}$, L J van't Veer ${ }^{47}$, P A Fasching ${ }^{48,49}$, S P Renner ${ }^{48}$, A B Ekici ${ }^{50}$, M W Beckmann ${ }^{48}$, C-Y Shen ${ }^{51,52}$, C-N Hsiung ${ }^{51}$, J-C Yu ${ }^{53}$, M-F Hou ${ }^{54,55}$, W Blot ${ }^{56}$, Q Cai ${ }^{56}$, A H Wu ${ }^{57}$, C-C Tseng ${ }^{57}$, D Van Den Berg ${ }^{57}$, D O Stram ${ }^{57}$, A Cox ${ }^{58}$, I W Brock ${ }^{58}$, M W R Reed ${ }^{58}$, K Muir $^{59,60}$, A Lophatananon ${ }^{60}$, S Stewart-Brown ${ }^{60}$, P Siriwanarangsan ${ }^{61}$, W Zheng ${ }^{62}$, S Deming-Halverson ${ }^{62}$, M J Shrubsole ${ }^{62}$, J Long ${ }^{62}$, X-O Shu ${ }^{62}$, W Lu ${ }^{63}$, Y-T Gao ${ }^{64}$, B Zhang ${ }^{62}$, P Radice ${ }^{65}$, P Peterlongo ${ }^{66}$, S Manoukian ${ }^{67}$, F Mariette ${ }^{66,68}$, S Sangrajrang ${ }^{69}$, J McKay ${ }^{70}$, F J Couch ${ }^{71}$, A E Toland ${ }^{72}$, TNBCC $^{73}$, D Yannoukakos ${ }^{74}$, O Fletcher ${ }^{75}$, N Johnson ${ }^{75}$,

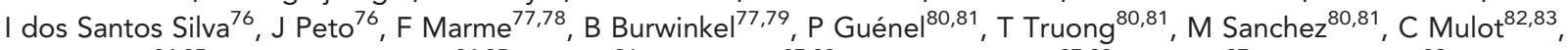

S E Bojesen ${ }^{84,85}$, B G Nordestgaard ${ }^{84,85}$, H Flyer ${ }^{86}$, H Brenner $^{87,88}$, A K Dieffenbach ${ }^{87,88}$, V Arndt ${ }^{87}$, C Stegmaier ${ }^{89}$, A Mannermaa ${ }^{90,91,92}$ V Kataja $91,93,94$, V-M Kosma 90,91,92, J M Hartikainen ${ }^{90,91,92}$, D Lambrechts ${ }^{95}$, B T Yesilyurt ${ }^{95}$, G Floris ${ }^{96}$, K Leunen ${ }^{96}$, J Chang-Claude ${ }^{97}$, A Rudolph ${ }^{97}$, P Seibold ${ }^{97}$, D Flesch-Janys ${ }^{98,99}$, X Wang $^{71}$, J E Olson ${ }^{100}$, C Vachon ${ }^{100}$, K Purrington ${ }^{100}$, G G Giles ${ }^{30,101}, \mathrm{G} \mathrm{Severi}{ }^{30,101}$, L Baglietto ${ }^{30,101}$, C A Haiman ${ }^{57}$, B E Henderson ${ }^{57}$, F Schumacher ${ }^{57}$, L Le Marchand ${ }^{102}$, J Simard ${ }^{103}$, M Dumont ${ }^{103}$, M S Goldberg ${ }^{104,105}$, F Labrèche ${ }^{106}$, R Winqvist ${ }^{107}$, K Pylkäs ${ }^{107}$, A Jukkola-Vuorinen ${ }^{108}$, M Grip ${ }^{109}$, P Devilee ${ }^{110}$, R A E M Tollenaar ${ }^{111}$, C Seynaeve $^{112}$, M García-Closas ${ }^{13,113,114}$, S J Chanock ${ }^{113}$, J Lissowska ${ }^{115}$, J D Figueroa ${ }^{113}, K$ Czene $^{116}$, M Eriksson ${ }^{116}, \mathrm{~K} \mathrm{Humphreys}^{116}$, H Darabi ${ }^{116}$, M J Hooning ${ }^{112}$, M Kriege ${ }^{112}$, J M Collée ${ }^{117}$, M Tilanus-Linthorst ${ }^{118}, \mathrm{~J} \mathrm{Li}^{119}$, A Jakubowska ${ }^{120}$, J Lubinski ${ }^{120}$, K Jaworska-Bieniek ${ }^{120}$, K Durda ${ }^{120}$, H Nevanlinna ${ }^{121}$, T A Muranen ${ }^{121}$, K Aittomäki $^{122}$, C Blomqvist $^{123}$, N Bogdanova ${ }^{124,125}$, T Dörk ${ }^{124}$, P Hall ${ }^{116}$, G Chenevix-Trench $^{19}$, D F Easton ${ }^{3,42}$, P D P Pharoah ${ }^{3,42}$, J I Arias-Perez ${ }^{126}$, P Zamora ${ }^{127}$, J Benítez ${ }^{1,5}$ and R L Milne ${ }^{\star 1,30,101}$

Author affiliations can be found at the end of this article

Background: Breast cancer is one of the most common malignancies in women. Genome-wide association studies have identified FGFR2 as a breast cancer susceptibility gene. Common variation in other fibroblast growth factor (FGF) receptors might also modify risk. We tested this hypothesis by studying genotyped single-nucleotide polymorphisms (SNPs) and imputed SNPs in FGFR1, FGFR3, FGFR4 and FGFRL1 in the Breast Cancer Association Consortium.

Methods: Data were combined from 49 studies, including 53835 cases and 50156 controls, of which 89050 (46450 cases and 42600 controls) were of European ancestry, 12893 (6269 cases and 6624 controls) of Asian and 2048 (1116 cases and 932 controls) of African ancestry. Associations with risk of breast cancer, overall and by disease sub-type, were assessed using unconditional logistic regression.

Results: Little evidence of association with breast cancer risk was observed for SNPs in the FGF receptor genes. The strongest evidence in European women was for rs743682 in FGFR3; the estimated per-allele odds ratio was 1.05 ( $95 \%$ confidence interval $=1.02-1.09, P=0.0020)$, which is substantially lower than that observed for SNPs in FGFR2.

Conclusion: Our results suggest that common variants in the other FGF receptors are not associated with risk of breast cancer to the degree observed for FGFR2.

*Correspondence: RL Milne; E-mail: roger.milne@cancervic.org.au

Received 4 September 2013; revised 8 November 2013; accepted 15 November 2013

(C) 2014 Cancer Research UK. All rights reserved 0007 - 0920/14 
Breast cancer is a complex disease, with multiple genetic and environmental factors involved in its etiology. Rare mutations in the DNA repair genes $B R C A 1$ and $B R C A 2$ confer a high lifetime risk of breast cancer (Antoniou et al, 2003) and are routinely screened for in women with a strong family history of the disease. Studies focused on other DNA repair genes have led to the discovery that rare coding variants in CHEK2, ATM, BRIP1 and PALB2 (Swift et al, 1987; Meijers-Heijboer et al, 2002; Seal et al, 2006; Rahman et al, 2007) are associated with moderately increased breast cancer risk. However, few, if any, candidate-gene- or pathway-based association studies have identified convincing associations with breast cancer risk for common genetic variants (The Breast Cancer Association Consortium, 2006). In contrast, empirical genome-wide association studies (GWAS) have proven to be a successful approach to identify common variants associated with small increases in risk, with more than 70 identified in this way to date (Easton et al, 2007; Hunter et al, 2007; Stacey et al, 2007, 2008; Ahmed et al, 2009; Thomas et al, 2009; Zheng et al, 2009; Antoniou et al, 2010; Turnbull et al, 2010; Cai et al, 2011; Fletcher et al, 2011; Haiman et al, 2011; Ghoussaini et al, 2012; Siddiq et al, 2012; Bojesen et al, 2013; Garcia-Closas et al, 2013; Michailidou et al, 2013). For the great majority of these associations, the causal variant(s), and even the causal gene, are unknown; thus, the identification of novel candidate genetic susceptibility pathways through this approach is not straightforward.

An intronic variant in the FGFR2 gene was one of the first single-nucleotide polymorphisms (SNPs) identified by GWAS as tagging a breast cancer susceptibility locus (Easton et al, 2007; Hunter et al, 2007). It is now well-established that the minor allele of this SNP is associated with increased risk of breast cancer, particularly estrogen receptor (ER)-positive disease (Garcia-Closas et al, 2008). Fine-mapping of the region has suggested that at least one causal variant is located in intron 2 of FGFR2 (Easton et al, 2007; Udler et al, 2009), and functional studies have proposed that rs2981578 affects FGFR2 expression (Meyer et al, 2008; Udler et al, 2009; Huijts et al, 2011). These findings strongly suggest that FGFR2 is a breast cancer susceptibility gene.

FGFR2 is a fibroblast growth factor (FGF) receptor gene; the amino-acid sequence of the protein it encodes is highly conserved across all FGF receptors. The other FGF receptor genes and other genes acting downstream of them in the FGF pathway may also be implicated in the development of breast cancer, although associations with disease risk have not been assessed comprehensively by a study with adequate sample size to detect odds ratios (ORs) of the magnitude observed for SNPs in FGFR2.

We hypothesised that common variants in other genes in the FGF pathway, and in the other FGF receptor genes in particular, might also confer increased breast cancer risk. The primary aim of our investigation was to comprehensively assess associations between breast cancer risk and common variation in the FGF receptor genes FGFR1, FGFR3, FGFR4 and FGFRL1 by genotyping selected tag-SNPs in the Breast Cancer Association Consortium (BCAC). A secondary objective was to assess common variants in other genes in the FGF pathway based on a two-stage design.

\section{MATERIALS AND METHODS}

Participants. Study participants were women from 49 studies participating in BCAC: 38 from populations of predominantly European ancestry, 9 of Asian women and 2 of African-American women (Table 1 and Supplementary Table 1). The majority were population-based or hospital-based case-control studies, but some studies selected subjects based on age or oversampled for cases with a family history or bilateral disease. Cases and controls from the CNIO-BCS were also studied in a previous assessment of selected genes in the FGF pathway. All study participants gave informed consent and each study was approved by the corresponding local ethics committee.

Gene and SNP selection. Ingenuity Pathways Analysis and selected publications (Eswarakumar et al, 2005; Presta et al, 2005; Chen \& Forough, 2006; Schwertfeger, 2009) were used to identify genes reported to be involved downstream of the FGF genes in the FGF pathway, particularly those related to angiogenesis. A total of 39 genes, including the FGF receptors FGFR1 (located at 8p11.22), FGFR2 (10q26.13), FGFR3 (4p16.3), FGFR4 (5q35.2) and FGFRL1 (4p16.3), was selected for tagging. Singlenucleotide polymorphisms with minor allele frequency (MAF) $>5 \%$ in the coding and non-coding regions, and within $5 \mathrm{~kb}$ upstream and $5 \mathrm{~kb}$ downstream of each gene, were identified using HapMap CEU genotype data and dbSNP 128 as reference. The minimum number of tag-SNPs were then selected among all identified SNP using Haploview (Barrett et al, 2005) based on the following criteria: $r^{2}>0.8$ and Illumina assay score $>0.60$. A total of 384 SNPs tagging 39 genes was genotyped in the CNIO-BCS, 324 of which were successfully genotyped (Supplementary Table 2). The 31 SNPs tagging genes FGFR1, FGFR3, FGFR4 and FGFRL1 were all genotyped in BCAC, along with a further 26 of the 324 tag-SNPs. The latter group comprised SNPs selected based on evidence of association with breast cancer under a log-additive model in the Stage 1 CNIO-BCS. Single-nucleotide polymorphisms in FGFR2 were not considered, as all were included as part of a separate fine-mapping study (Meyer et al, submitted). Results from Stage 1 are summarised in Supplementary Table 2.

Genotyping. Genotyping of the 57 SNPs in the BCAC samples was conducted using a custom Illumina Infinium array (iCOGS) in four centers, as part of a multi-consortia collaboration (the Collaborative Oncological Gene-Environment Study, COGS) as described previously (Michailidou et al, 2013). Genotypes were called using Illumina's proprietary GenCall algorithm.

For the genotyping of the 384 SNPs in the Stage 1 CNIO-BCS, genomic DNA was isolated from peripheral blood lymphocytes using automatic DNA extraction (MagNA Pure, Roche Diagnostics, Indianapolis, IN, USA) according to the manufacturer's recommended protocols. This DNA was quantified using Picogreen (Invitrogen, Life Technologies, Grand Island, NY, USA) and for each sample a final quantity of $250 \mathrm{ng}$ was extracted and used for GoldenGate genotyping with VeraCode Technology (Illumina Inc., San Diego, CA, USA). Samples were arranged on 25 96-well plates containing one negative control and at least one study sample in duplicate. Three Centre d'Etude du Polymorphisme Humain (CEPH) trios were used as internal intra- and inter-plate duplicates and to check for Mendelian segregation errors. DNA was extracted, quantified, plated and genotyped at the Spanish National Genotyping Centre (CeGen), Madrid, Spain. All genotypes were determined for each SNP and each plate using manual clustering. Single-nucleotide polymorphisms with call rate $<90 \%$ were excluded, as were samples with no-calls for more than $20 \%$ of included SNPs.

Statistical methods. For each SNP, we estimated ORs and 95\% confidence intervals (CIs) using unconditional logistic regression. For the analysis of BCAC data, we considered per-allele and codominant models using common-allele homozygotes as reference and including study and ethnicity-specific principal components as covariates, as previously described (Michailidou et al, 2013). Departure from the Hardy-Weinberg equilibrium (HWE) was tested for in controls from individual studies using the genhwi module in STATA 11.2 (College Station, TX, USA). A studystratified $\chi^{2}$ test (1df) was applied across studies (Haldane, 1954; Robertson \& Hill, 1984). Between-study heterogeneity in ORs was 
assessed for each of the three broad racial groups using the metan command in STATA to meta-analyse study-specific per-allele log-OR estimates and generate $I^{2}$ statistics; values greater than $50 \%$ were considered notable (Higgins \& Thompson, 2002). Odds ratios specific to disease subtypes defined by ER, PR and HER2 status (positive and negative) were estimated separately for each ethnic subgroup using polytomous logistic regression with control status as the reference outcome. Differences in ORs by disease subtypes were assessed using a likelihood ratio test (LRT). All statistical tests were two-sided.

The effective number of independent SNPs $\left(\mathrm{V}_{\text {effLi }}\right)$ was estimated using the method described by Li \& Ji (2005). This method was applied via the web-interface matSpDlite (http:// gump.qimr.edu.au/general/daleN/matSpDlite/), based on the observed correlations between SNPs (Nyholt, 2004). $\mathrm{V}_{\text {effLi }}$ was then used to calculate a Bonferroni-corrected significance threshold $\left(\alpha^{*}\right)$. Power calculations were carried out using Quanto v1.2.4 (http://hydra.usc.edu/gxe/).

Single-nucleotide polymorphism imputation. The genotypes of untyped SNPs were imputed based on data from the March 2012 release of the 1000 genomes project using IMPUTE v2.2. These were converted to allele doses using the impute2mach function in the GenABEL library in $\mathrm{R}$ (Aulchenko et al, 2007) and analysed under a per-allele model. Imputed SNPs with an estimated MAF $<5 \%$ were excluded, as were SNPs with an imputation $r^{2}<80 \%$.

\section{RESULTS}

All SNPs in the present analysis had overall call rates $>95 \%$. Very strong evidence of departure from HWE was observed for rs34869253 for one study (pKarma, $P=3.3 \times 10^{-21}$ ), which was excluded from the subsequent analyses of that SNP. After quality control, there were data available for 53835 cases and 50156 controls from BCAC, including 89050 European women (46450 cases and 42600 controls), 12893 Asian (6269 cases and 6624 controls) and 2048 African-American women (1116 cases and 932 controls) (Table 1).

Results from the analysis of the 31 tag-SNPs in FGFR genes for white Europeans are summarised in Table 2. No strong evidence of association was observed, although one SNP (rs743682) in FGFR3 (MAF $=9 \%$ ) was marginally significant after correction for multiple testing based on a $\mathrm{V}_{\text {effLi }}$ of 23 (per-allele $\mathrm{OR}=1.05,95 \% \mathrm{CI}=1.02-1.09, P=0.0020, \alpha^{*}=0.0022$ ). All SNPs with an associated $P$-value $<0.05$ were intronic, with the exception of rs1966265, which is a missense variant in FGFR4. However, PolyPhen (http://genetics.bwh.harvard.edu/ pph2/) predicts this amino acid change to be benign, with a score of 0.000 . On the basis of ENCODE data, no SNP with an associated $P$-value $<0.05$ was located in a region involved or predicted to be involved in epigenetic regulation, nor at, or within $2 \mathrm{~kb}$ of, a CpG island. For European women, we did not observe any evidence of between-study heterogeneity for any SNPs $\left(I^{2} \leqslant 19 \% ; P \geqslant 0.15\right)$ and little evidence of differential associations by disease subtypes defined by $\operatorname{ER~}(P \geqslant 0.036)$, PR $(P \geqslant 0.084)$ or HER2 status $(P \geqslant 0.019)$.

We similarly observed little evidence of association with overall breast cancer risk in Asian and African-American women (Supplementary Tables 3 and 4, respectively). Nevertheless, a consistent result was observed for Europeans and Asians for rs1966265 in FGFR4. The estimated OR per risk (G) allele was 1.03 $(95 \% \mathrm{CI}=1.01-1.05 ; P=0.0060)$ for European women and 1.08 $(95 \% \mathrm{CI}=1.03-1.14 ; P=0.0036)$ for Asian women. There was no evidence of heterogeneity by race for any of the 31 SNPs in FGF receptors $\left(I^{2}=18 \% ; P=0.14\right)$.

The SNPs genotyped were estimated to capture a variable proportion of the common variation in the four genes considered, as described in the 1000 genomes project; at $r^{2} \geqslant 0.80$, this coverage was $75 \%$ for FGFR1, 77\% for FGFR3, 66\% for FGFR4 and $17 \%$ for FGFRL1. This coverage was dramatically improved with the inclusion of imputed common SNPs (with imputation $r^{2}>0.80$ ) to $95 \%, 93 \%, 97 \%$ and $84 \%$ for FGFR1, FGFR3, FGFR4 and FGFRL1, respectively. No stronger evidence of association was observed for any imputed SNPs (Supplementary Tables 5-8).

Finally, we observed little evidence of association for any of the 26 SNPs in other genes in the FGF pathway, selected based on results from Stage 1 (Supplementary Table 9). The results were consistent across the three ethnic groups considered and for disease subtypes defined by ER, PR and HER2 expression.

It is noteworthy that strong association signals were observed in the Stage 1 Spanish study for selected tag-SNPs rs10736303 $(\mathrm{MAF}=0.49$; per-allele $\mathrm{OR}=1.37,95 \% \mathrm{CI}=1.21-1.55, \quad P=2.8$ $\left.\times 10^{-7}\right)$, and $\mathrm{rs} 2981582(\mathrm{MAF}=0.40$; per-allele $\mathrm{OR}=1.35,95 \%$ $\left.\mathrm{CI}=1.19-1.53, P=8.3 \times 10^{-7}\right)$, both in FGFR2.

\section{DISCUSSION}

In this multicentre case-control study, we comprehensively assessed common variation in the FGF receptor genes FGFR1, FGFR3, FGFR4 and FGFRL1 in 53835 cases and 50156 controls and found little evidence of association with risk of breast cancer. This is the largest study we know of assessing a family of genes via a candidate approach based on the findings from GWAS.

A non-trivial issue in analyses of this kind is the establishment of a statistical significance threshold that adequately controls the proportion of false-positive findings. As permutation-testing was not feasible due to the sample size and number of dummy variables required to adjust for study, we dealt with the issue of nonindependence of multiple tests by estimating that the 31 tag-SNPs represented an effective number of 23 independent variables, and applying a Bonferroni correction accordingly. The association of one SNP (rs743682) in FGFR3 for European women was found to be statistically significant on this basis. However, the $P$-value threshold applied is somewhat questionable in the context of the total of more than 70000 SNPs nominated for genotyping by BCAC and the total 210000 genotyped on the iCOGS array. Thus, the current result is far from genome-wide statistical significance and certainly requires independent replication. In any case, the per-allele ORs for FGFR3_rs743682 $(1.05,95 \% \mathrm{CI}=1.02-1.09)$ and FGFR4_rs1966265 (1.03, 95\% CI =1.01-1.05) appear to be substantially lower than that for rs2981582 in FGFR2 (1.26, 95\% $\mathrm{CI}=1.23-1.30)$ (Easton et al, 2007).

We estimated that for common SNPs (MAF >0.05) associated with overall breast cancer risk in European women, we had greater than $99 \%$ power to detect at genome-wide statistical significance $\left(P<5 \times 10^{-8}\right)$ a per-allele $\mathrm{OR}$ as low as 1.23 (the lower $95 \%$ confidence limit for the OR for FGFR2_rs2981582). For a per-allele OR as low as 1.05 and for SNPs with MAF of 0.10, 0.20 and 0.30, the estimated power was $1 \%, 10 \%$ and $24 \%$, respectively. That is, our study provides strong evidence that common variation in FGFR1, FGFR3, FGFR4 and FGFRL1 are not associated with breast cancer risk to the degree observed for SNPs in FGFR2, although associations of smaller magnitude may exist.

The hypothesis underlying our study was based on the identification of a functional SNP in intron 2 of FGFR2 associated with breast cancer susceptibility (Easton et al, 2007; Meyer et al, 2008; Udler et al, 2009; Huijts et al, 2011). A recent study has subsequently identified three independent risk signals within FGFR2, and uncovered likely causal variants and functional mechanisms behind them (Meyer et al, 2013). Although an association between these SNPs and expression of FGFR2 has not been established, these results provide strong 
Table 1. Number of cases and controls included, by study

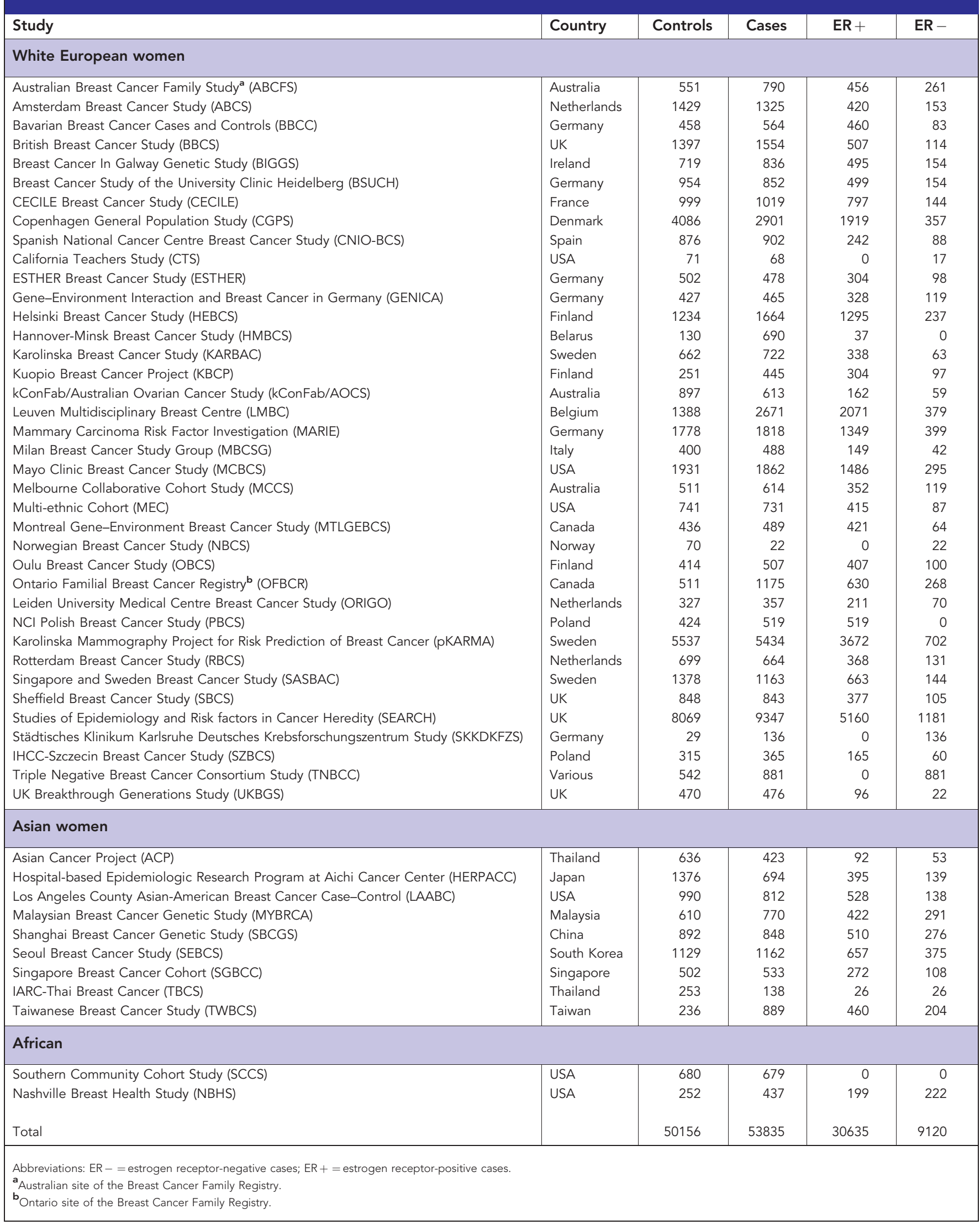

evidence that FGFR2 is the target gene, and it therefore seems plausible that other FGF receptors or genes acting in the FGF pathway might also be implicated in breast cancer risk. However, we find little evidence that this is the case for the receptors, at least not to the extent observed for common variants in FGFR2. Admittedly, the degree to which common variation in the FGF 
Table 2. Summary results for SNPs in FGF receptor genes for white European women

OR $(95 \% \mathrm{Cl})$

OR $(95 \% \mathrm{Cl})$

\begin{tabular}{|c|c|c|c|c|c|c|c|c|c|}
\hline SNP & Alleles & MAF & $\mathrm{Aa}$ & aа & per-a-allele & $\boldsymbol{P}$ & $\mathrm{ER}-$ & ER + & P-het \\
\hline \multicolumn{10}{|l|}{ FGFR1 } \\
\hline rs10958704 & AG & 0.40 & $0.98(0.95-1.01)$ & $0.98(0.94-1.02)$ & $0.99(0.97-1.01)$ & 0.18 & $0.99(0.96-1.03)$ & $0.99(0.97-1.02)$ & 0.91 \\
\hline rs17182141 & AG & 0.06 & $1.05(1.00-1.09)$ & $0.95(0.75-1.22)$ & $1.04(1.00-1.08)$ & 0.057 & $1.08(1.00-1.17)$ & $1.04(0.99-1.09)$ & 0.30 \\
\hline rs2288696 & GA & 0.21 & $1.02(0.99-1.05)$ & $1.07(1.00-1.14)$ & $1.03(1.00-1.05)$ & 0.023 & $1.05(1.01-1.10)$ & $1.03(1.00-1.06)$ & 0.35 \\
\hline rs2411256 & GA & 0.24 & $1.02(0.99-1.05)$ & $1.01(0.95-1.07)$ & $1.01(0.99-1.03)$ & 0.36 & $1.00(0.95-1.04)$ & $1.01(0.99-1.04)$ & 0.44 \\
\hline rs2978076 & GA & 0.08 & $0.99(0.96-1.03)$ & $1.22(1.04-1.44)$ & $1.01(0.98-1.05)$ & 0.53 & $0.99(0.92-1.06)$ & $1.02(0.98-1.06)$ & 0.37 \\
\hline rs2978083 & GA & 0.05 & $0.99(0.96-1.03)$ & $1.22(1.04-1.44)$ & $1.01(0.98-1.05)$ & 0.53 & $0.97(0.89-1.06)$ & $1.03(0.97-1.08)$ & 0.27 \\
\hline rs3758102 & GA & 0.26 & $1.01(0.98-1.04)$ & $1.02(0.96-1.07)$ & $1.01(0.99-1.03)$ & 0.35 & $1.01(0.97-1.05)$ & $1.01(0.98-1.04)$ & 0.95 \\
\hline rs3925 & GA & 0.23 & $1.01(0.98-1.04)$ & $1.00(0.95-1.07)$ & $1.01(0.99-1.03)$ & 0.51 & $0.99(0.95-1.04)$ & $1.01(0.99-1.04)$ & 0.39 \\
\hline rs 4733930 & $\mathrm{GA}$ & 0.42 & $1.00(0.97-1.03)$ & $1.04(1.00-1.08)$ & $1.02(1.00-1.04)$ & 0.11 & $1.03(0.99-1.07)$ & $1.02(1.00-1.04)$ & 0.67 \\
\hline rs 4733946 & $\mathrm{CA}$ & 0.08 & $1.00(0.97-1.03)$ & $1.04(1.00-1.08)$ & $1.02(1.00-1.04)$ & 0.11 & $1.01(0.95-1.08)$ & $1.04(1.00-1.09)$ & 0.39 \\
\hline rs6474354 & GA & 0.21 & $0.98(0.95-1.01)$ & $0.99(0.92-1.05)$ & $0.98(0.96-1.01)$ & 0.18 & $0.96(0.92-1.01)$ & $0.98(0.96-1.01)$ & 0.37 \\
\hline rs6996321 & GA & 0.39 & $1.01(0.98-1.04)$ & $1.00(0.96-1.04)$ & $1.00(0.98-1.02)$ & 0.95 & $1.00(0.97-1.04)$ & $0.99(0.97-1.02)$ & 0.54 \\
\hline rs6983315 & GA & 0.44 & $1.01(0.97-1.04)$ & $0.98(0.94-1.02)$ & $0.99(0.97-1.01)$ & 0.39 & $0.97(0.93-1.00)$ & $0.99(0.97-1.02)$ & 0.13 \\
\hline rs7012413 & GA & 0.30 & $1.00(0.97-1.02)$ & $0.99(0.95-1.04)$ & $1.00(0.98-1.02)$ & 0.69 & $1.00(0.97-1.04)$ & $1.00(0.98-1.02)$ & 0.82 \\
\hline \multicolumn{10}{|l|}{ FGFR3 } \\
\hline rs12502543 & GA & 0.10 & $1.04(1.01-1.08)$ & $1.10(0.96-1.25)$ & $1.04(1.01-1.08)$ & 0.0076 & $0.99(0.93-1.05)$ & $1.06(1.02-1.10)$ & 0.036 \\
\hline rs2234909 & $A G$ & 0.14 & $0.99(0.95-1.02)$ & $0.97(0.88-1.07)$ & $0.99(0.96-1.01)$ & 0.29 & $0.99(0.94-1.04)$ & $0.98(0.95-1.02)$ & 0.77 \\
\hline rs3135848 & AG & 0.28 & $1.02(0.99-1.04)$ & $1.02(0.96-1.07)$ & $1.01(0.99-1.03)$ & 0.31 & $1.00(0.96-1.04)$ & $1.01(0.99-1.04)$ & 0.55 \\
\hline rs743682 & GA & 0.09 & $1.05(1.01-1.09)$ & $1.16(1.00-1.34)$ & $1.05(1.02-1.09)$ & 0.0020 & $1.01(0.95-1.08)$ & $1.06(1.02-1.10)$ & 0.24 \\
\hline rs746779 & GA & 0.18 & $0.99(0.96-1.02)$ & $0.98(0.90-1.06)$ & $0.99(0.96-1.01)$ & 0.29 & $1.00(0.95-1.05)$ & $0.98(0.95-1.01)$ & 0.48 \\
\hline \multicolumn{10}{|l|}{ FGFR4 } \\
\hline rs1076891 & GA & 0.06 & $1.03(0.99-1.08)$ & $0.99(0.81-1.22)$ & $1.03(0.99-1.07)$ & 0.14 & $1.06(0.98-1.14)$ & $1.01(0.97-1.06)$ & 0.25 \\
\hline rs1966265 & GA & 0.23 & $0.97(0.94-1.00)$ & $0.93(0.88-0.99)$ & $0.97(0.95-0.99)$ & 0.0060 & $0.98(0.94-1.03)$ & $0.97(0.95-1.00)$ & 0.54 \\
\hline rs2456173 & $\mathrm{GA}$ & 0.21 & $1.00(0.97-1.03)$ & $0.99(0.92-1.05)$ & $0.99(0.97-1.02)$ & 0.66 & $0.98(0.94-1.02)$ & $1.00(0.98-1.03)$ & 0.34 \\
\hline rs376618 & AG & 0.24 & $1.00(0.97-1.03)$ & $0.96(0.91-1.02)$ & $0.99(0.97-1.01)$ & 0.33 & $0.97(0.93-1.01)$ & $0.99(0.97-1.02)$ & 0.29 \\
\hline rs641101 & GA & 0.31 & $1.01(0.98-1.04)$ & $0.99(0.94-1.03)$ & $1.00(0.98-1.02)$ & 0.98 & $0.99(0.95-1.03)$ & $1.00(0.98-1.02)$ & 0.56 \\
\hline rs6556301 & CA & 0.36 & $0.99(0.97-1.02)$ & $0.96(0.92-1.00)$ & $0.98(0.97-1.00)$ & 0.13 & $0.99(0.95-1.02)$ & $0.98(0.96-1.01)$ & 0.84 \\
\hline \multicolumn{10}{|l|}{ FGFRL1 } \\
\hline rs 34869253 & AG & 0.43 & $1.00(0.97-1.04)$ & $1.00(0.96-1.04)$ & $1.00(0.98-1.02)$ & 0.96 & $0.98(0.94-1.01)$ & $0.99(0.97-1.01)$ & 0.52 \\
\hline rs3755955 & GA & 0.16 & $1.00(0.97-1.03)$ & $1.02(0.94-1.11)$ & $1.00(0.98-1.03)$ & 0.82 & $1.00(0.95-1.05)$ & $1.00(0.97-1.03)$ & 0.83 \\
\hline rs4505759 & GA & 0.30 & $0.99(0.96-1.02)$ & $0.98(0.93-1.03)$ & $0.99(0.97-1.00)$ & 0.38 & $1.00(0.96-1.04)$ & $0.99(0.97-1.02)$ & 0.78 \\
\hline rs4647932 & GA & 0.06 & $1.04(0.99-1.08)$ & $0.98(0.80-1.20)$ & $1.03(0.99-1.07)$ & 0.14 & $1.06(0.98-1.14)$ & $1.02(0.97-1.06)$ & 0.31 \\
\hline rs6855233 & $A G$ & 0.29 & $0.99(0.97-1.02)$ & $1.03(0.98-1.08)$ & $1.01(0.98-1.03)$ & 0.62 & $0.98(0.94-1.02)$ & $1.00(0.98-1.03)$ & 0.31 \\
\hline rs748651 & AG & 0.48 & $1.00(0.97-1.03)$ & $1.02(0.98-1.06)$ & $1.01(0.99-1.03)$ & 0.31 & $1.03(0.99-1.07)$ & $1.01(0.98-1.03)$ & 0.22 \\
\hline
\end{tabular}

Abbreviations: $\mathrm{SNP}=$ single-nucleotide polymorphism; FGF = fibroblast growth factor; $\mathrm{OR}=$ odds ratio where $\mathrm{A}$ is the common allele, a is the rare allele and both $\mathrm{Aa}$ and aa are compared with AA genotypes; $\mathrm{Cl}=$ confidence interval; $\mathrm{MAF}=$ minor allele frequency; $P=P$-value for the per-a-allele model; $E R-=$ results (per a-allele) for risk of estrogen receptor-negative disease; $\mathrm{ER}+=$ results (per a-allele) for risk of estrogen receptor-positive disease; $P$-het $=P$-value for heterogeneity by disease sub-type defined by estrogen receptor status.

receptor genes was tagged by the genotyped SNPs was good for FGFR1, FGFR3 and FGFR4 and poor for FGFRL1, but substantial improvement was afforded by imputation. Nevertheless, it is possible that common variation not captured by the genotyped or imputed SNPs may be associated with breast cancer risk. It is also possible that these genes may be implicated in disease susceptibility via regulatory mechanisms involving variants outside the chromosomal boundaries defined for each gene considered. That said, few studies have assessed common variation in candidate genes to this extent, in terms of both gene coverage and sample size.

The power of our study was much lower for Asian and African-American women; however, our primary focus on European women is consistent with our hypothesis, based on the previous finding in FGFR2 in this population. Our study was also limited by the power and gene coverage of the stage 1 component which assessed tag-SNPs in the selected genes of the FGF pathway. Therefore, no conclusions can be drawn about the potential implication of common variation in these genes in breast cancer susceptibility. Nevertheless, we checked the chromosomal locations of the 76 established risk-associated loci (http://www.nature.com/icogs/primer/shared-susceptibilityloci-for-breast-prostate-and-ovarian-cancers/) and found that none were located within $10 \mathrm{~kb}$ of any of the 39 genes considered, with the exception of the FGFR2 locus.

In conclusion, in this, possibly the largest candidate-gene association study carried out to date, we have observed little evidence of association between common variation in the FGFR1, FGFR3, FGFR4 and FGFRL1 genes and risk of breast cancer. Our results suggest that common variants in these FGF receptors are not associated with risk of breast cancer to the degree observed for FGFR2.

\section{ACKNOWLEDGEMENTS}

We thank all the individuals who took part in these studies and all the researchers, study staff, clinicians and other health-care 
providers, technicians and administrative staff who have enabled this work to be carried out. In particular, we thank: Andrew Berchuck (OCAC), Rosalind A Eeles, Ali Amin Al Olama, Zsofia Kote-Jarai, Sara Benlloch (PRACTICAL), Antonis Antoniou, Lesley McGuffog, Ken Offit (CIMBA), Andrew Lee, and Ed Dicks, Craig Luccarini and the staff of the Centre for Genetic Epidemiology Laboratory, Daniel C Tessier, Francois Bacot, Daniel Vincent, Sylvie LaBoissière, Frederic Robidoux and the staff of the McGill University and Génome Québec Innovation Centre, Sune F Nielsen, and the staff of the Copenhagen DNA laboratory, Julie M Cunningham, Sharon A Windebank, Christopher A Hilker, Jeffrey Meyer and the staff of Mayo Clinic Genotyping Core Facility, Maggie Angelakos, Judi Maskiell, Sten Cornelissen, Ellen van der Schoot, Emiel Rutgers, Senno Verhoef, Frans Hogervorst, the Thai Ministry of Public Health (MOPH), Dr Prat Boonyawongviroj (former Permanent Secretary of MOPH), Dr Pornthep Siriwanarungsan (Department Director-General of Disease Control), Alexander Hein, Michael Schrauder, Matthias Rübner, Sonja Oeser, Silke Landrith, Eileen Williams, Elaine Ryder-Mills, Kara Sargus, Niall McInerney, Gabrielle Colleran, Andrew Rowan, Angela Jones, Christ of Sohn, Andeas Schneeweiß, Peter Bugert, the Danish Breast Cancer Group, Ana Osorio, Alicia Barroso, Victoria Fernández, Maika González-Neira, Núria Malats, Francisco Real, Belén Herráez, Núria Álvarez, Esther Díaz, María Miguel-Martin, the CTS Steering Committee (including: Leslie Bernstein, James Lacey, Sophia Wang, Huiyan Ma, Yani Lu and Jessica Clague DeHart at the Beckman Research Institute of the City of Hope; Dennis Deapen, Rich Pinder, Eunjung Lee and Fred Schumacher at the University of Southern California; Pam HornRoss, Peggy Reynolds and David Nelson at the Cancer Prevention Institute of California; and Hannah Park at the University of California Irvine), Hartwig Ziegler, Sonja Wolf, Volker Hermann, The GENICA network (Dr Margarete Fischer-Bosch Institute of Clinical Pharmacology, Stuttgart, and University of Tübingen, Germany; (HB, Wing-Yee Lo, Christina Justenhoven), Department of Internal Medicine, Evangelische Kliniken Bonn $\mathrm{GmbH}$, Johanniter Krankenhaus, Bonn, Germany (Yon-Dschun Ko, Christian Baisch), Institute of Pathology, University of Bonn, Germany (Hans-Peter Fischer), Molecular Genetics of Breast Cancer, Deutsches Krebsforschungszentrum (DKFZ) Heidelberg, Germany (UH), Institute for Prevention and Occupational Medicine of the German Social Accident Insurance, Institute of the Ruhr University Bochum (IPA), Germany (TB, Beate Pesch, Sylvia Rabstein, Anne Lotz), Institute of Occupational Medicine and Maritime Medicine, University Medical Center HamburgEppendorf, Germany (Volker Harth)), Tuomas Heikkinen, Irja Erkkilä, Kirsimari Aaltonen, Karl von Smitten, Natalia Antonenkova, Peter Hillemanns, Hans Christiansen, Eija Myöhänen, Helena Kemiläinen, Heather Thorne, Eveline Niedermayr, the AOCS Management Group (D Bowtell, G Chenevix-Trench, A deFazio, D Gertig, A Green, P Webb), the ACS Management Group (A Green, P Parsons, N Hayward, P Webb and D Whiteman), the LAABC data collection team, especially Annie Fung and June Yashiki, Gilian Peuteman, Dominiek Smeets, Thomas Van Brussel, Kathleen Corthouts, Nadia Obi, Judith Heinz, Sabine Behrens, Ursula Eilber, Muhabbet Celik, Til Olchers, Bernad Peissel, Giulietta Scuvera, Daniela Zaffaroni, Bernardo Bonanni, Monica Barile, Irene Feroce, the personnel of the Cogentech Cancer Genetic Test Laboratory, The Mayo Clinic Breast Cancer Patient Registry, Martine Tranchant, Marie-France Valois, Annie Turgeon, Lea Heguy, Phuah Sze Yee, Peter Kang, Kang In Nee, Shivaani Mariapun, Yoon Sook-Yee, Daphne Lee, Teh Yew Ching, Nur Aishah Mohd Taib, Meeri Otsukka, Kari Mononen, Teresa Selander, Nayana Weerasooriya, OFBCR staff, E Krol-Warmerdam, J Molenaar, J Blom, Louise Brinton, Neonila Szeszenia-Dabrowska, Beata Peplonska, Witold Zatonski, Pei Chao, Michael Stagner, Petra Bos, Jannet Blom, Ellen Crepin,
Anja Nieuwlaat, Annette Heemskerk, the Erasmus MC Family Cancer Clinic, Sue Higham, Simon Cross, Helen Cramp, Dan Connley, The Eastern Cancer Registration and Information Centre, the SEARCH and EPIC teams, Craig Luccarini, Don Conroy, Caroline Baynes, Kimberley Chua, the Ohio State University Human Genetics Sample Bank and Robert Pilarski. Data on SCCS cancer cases used in this publication were provided by the: Alabama Statewide Cancer Registry; Kentucky Cancer Registry, Lexington, KY; Tennessee Department of Health, Office of Cancer Surveillance; Florida Cancer Data System; North Carolina Central Cancer Registry, North Carolina Division of Public Health; Georgia Comprehensive Cancer Registry; Louisiana Tumor Registry; Mississippi Cancer Registry; South Carolina Central Cancer Registry; Virginia Department of Health, Virginia Cancer Registry; Arkansas Department of Health, Cancer Registry. BCAC is funded by Cancer Research UK (C1287/A10118, C1287/A12014) and by the European Community's Seventh Framework Programme under grant agreement number 223175 (HEALTH-F22009-223175) (COGS). Meetings of the BCAC have been funded by the European Union COST programme (BM0606). Genotyping of the iCOGS array was funded by the European Union (HEALTH-F2-2009-223175), Cancer Research UK (C1287/ A10710), the Canadian Institutes of Health Research for the 'CIHR Team in Familial Risks of Breast Cancer' programme, and the Ministry of Economic Development, Innovation and Export Trade of Quebec (PSR-SIIRI-701). Additional support for the iCOGS infrastructure was provided by the National Institutes of Health (CA128978) and Post-Cancer GWAS initiative (1U19 CA148537, 1U19 CA148065 and 1U19 CA148112 - the GAMEON initiative), the Department of Defence (W81XWH-10-1-0341), Komen Foundation for the Cure, the Breast Cancer Research Foundation, and the Ovarian Cancer Research Fund. The ABCFS and OFBCR work was supported by grant UM1 CA164920 from the National Cancer Institute (USA). The content of this manuscript does not necessarily reflect the views or policies of the National Cancer Institute or any of the collaborating centers in the Breast Cancer Family Registry (BCFR) nor does mention of trade names, commercial products or organizations imply endorsement by the US Government or the BCFR. The ABCFS was also supported by the National Health and Medical Research Council of Australia, the New South Wales Cancer Council, the Victorian Health Promotion Foundation (Australia) and the Victorian Breast Cancer Research Consortium. JLH is a National Health and Medical Research Council (NHMRC) Senior Principal Research Fellow and MCS is a NHMRC Senior Research Fellow. The OFBCR work was also supported by the Canadian Institutes of Health Research 'CIHR Team in Familial Risks of Breast Cancer' program. The ABCS was funded by the Dutch Cancer Society Grant no. NKI2007-3839 and NKI2009-4363. The ACP study is funded by the Breast Cancer Research Trust, UK. The work of the BBCC was partly funded by ELAN-Programme of the University Hospital of Erlangen. The BBCS is funded by Cancer Research UK and Breakthrough Breast Cancer and acknowledges NHS funding to the NIHR Biomedical Research Centre and the National Cancer Research Network (NCRN). ES is supported by NIHR Comprehensive Biomedical Research Centre, Guy's \& St. Thomas' NHS Foundation Trust in partnership with King's College London, United Kingdom. IT is supported by the Oxford Biomedical Research Centre. The BSUCH study was supported by the Dietmar-Hopp Foundation, the Helmholtz Society and the German Cancer Research Center (DKFZ). The CECILE study was funded by the Fondation de France, the French National Institute of Cancer (INCa), The National League against Cancer, the National Agency for Environmental and Occupational Health and Food Safety (ANSES), the National Agency for Research (ANR) and the Association for Research against Cancer (ARC). The CGPS was supported by the Chief Physician Johan Boserup and Lise 
Boserup Fund, the Danish Medical Research Council and Herlev Hospital. The CNIO-BCS was supported by the Genome Spain Foundation, the Red Temática de Investigación Cooperativa en Cáncer and grants from the Asociación Española Contra el Cáncer and the Fondo de Investigación Sanitario (PI11/00923 and PI081120). The Human Genotyping-CEGEN Unit, CNIO is supported by the Instituto de Salud Carlos III. DA was supported by a Fellowship from the Michael Manzella Foundation (MMF) and was a participant in the CNIO Summer Training Program. The CTS was initially supported by the California Breast Cancer Act of 1993 and the California Breast Cancer Research Fund (contract 97-10500) and is currently funded through the National Institutes of Health (R01 CA77398). Collection of cancer incidence data was supported by the California Department of Public Health as part of the statewide cancer reporting program mandated by California Health and Safety Code Section 103885. HAC receives support from the Lon V Smith Foundation (LVS39420). The ESTHER study was supported by a grant from the Baden Württemberg Ministry of Science, Research and Arts. Additional cases were recruited in the context of the VERDI study, which was supported by a grant from the German Cancer Aid (Deutsche Krebshilfe). The GENICA was funded by the Federal Ministry of Education and Research (BMBF) Germany grants 01KW9975/5, 01KW9976/8, 01KW9977/0 and 01KW0114, the Robert Bosch Foundation, Stuttgart, Deutsches Krebsforschungszentrum (DKFZ), Heidelberg, Institute for Prevention and Occupational Medicine of the German Social Accident Insurance, Institute of the Ruhr University Bochum (IPA) as well as the Department of Internal Medicine, Evangelische Kliniken Bonn GmbH, Johanniter Krankenhaus Bonn, Germany. The HEBCS was supported by the Helsinki University Central Hospital Research Fund, Academy of Finland (132473), the Finnish Cancer Society, The Nordic Cancer Union and the Sigrid Juselius Foundation. The HERPACC was supported by a Grant-in-Aid for Scientific Research on Priority Areas from the Ministry of Education, Science, Sports, Culture and Technology of Japan, by a Grant-in-Aid for the ThirdTerm Comprehensive 10-Year Strategy for Cancer Control from Ministry Health, Labour and Welfare of Japan, by a research grant from Takeda Science Foundation, by Health and Labour Sciences Research Grants for Research on Applying Health Technology from Ministry Health, Labour and Welfare of Japan and by National Cancer Center Research and Development Fund. The HMBCS was supported by short-term fellowships from the German Academic Exchange Program (to NB) and the Friends of Hannover Medical School (to NB)-Financial support for KARBAC was provided through the regional agreement on medical training and clinical research (ALF) between Stockholm County Council and Karolinska Institutet, the Stockholm Cancer Foundation and the Swedish Cancer Society. The KBCP was financially supported by the special Government Funding (EVO) of Kuopio University Hospital grants, Cancer Fund of North Savo, the Finnish Cancer Organizations, the Academy of Finland and by the strategic funding of the University of Eastern Finland. kConFab is supported by grants from the National Breast Cancer Foundation, the NHMRC, the Queensland Cancer Fund, the Cancer Councils of New South Wales, Victoria, Tasmania and South Australia and the Cancer Foundation of Western Australia. The kConFab Clinical Follow-Up Study was funded by the NHMRC (145684, 288704 and 454508). Financial support for the AOCS was provided by the United States Army Medical Research and Materiel Command (DAMD17-01-1-0729), the Cancer Council of Tasmania and Cancer Foundation of Western Australia and the NHMRC (199600). GCT and PW are supported by the NHMRC. LAABC is supported by grants (1RB-0287, 3PB-0102, 5PB-0018 and 10PB-0098) from the California Breast Cancer Research Program. Incident breast cancer cases were collected by the USC Cancer Surveillance Program (CSP) which is supported under subcontract by the California Department of Health. The CSP is also part of the National Cancer Institute's Division of Cancer Prevention and Control Surveillance, Epidemiology and End Results Program, under contract number N01CN25403. LMBC is supported by the 'Stichting tegen Kanker' (232-2008 and 196-2010). The MARIE study was supported by the Deutsche Krebshilfe e.V. (70-2892-BR I), the Federal Ministry of Education and Research (BMBF) Germany (01KH0402), the Hamburg Cancer Society and the German Cancer Research Center (DKFZ). MBCSG is supported by grants from the Italian Association for Cancer Research (AIRC) and by funds from the Italian citizens who allocated a 5 out of 1000 share of their tax payment in support of the Fondazione IRCCS Istituto Nazionale dei Tumori, according to Italian laws (INT-Institutional strategic projects " $5 \times 1000$ ") The MCBCS was supported by the NIH grants (CA122340 and CA128978) and a Specialized Program of Research Excellence (SPORE) in Breast Cancer (CA116201), the Breast Cancer Research Foundation and a generous gift from the David F and Margaret T Grohne Family Foundation and the Ting Tsung and Wei Fong Chao Foundation. MCCS cohort recruitment was funded by VicHealth and Cancer Council Victoria. The MCCS was further supported by Australian NHMRC grants 209057, 251553 and 504711 and by infrastructure provided by Cancer Council Victoria. The MEC was supported by NIH grants CA63464, CA54281, CA098758 and CA132839. The work of MTLGEBCS was supported by the Quebec Breast Cancer Foundation, the Canadian Institutes of Health Research (grant CRN-87521) and the Ministry of Economic Development, Innovation and Export Trade (grant PSR-SIIRI-701). MYBRCA is funded by research grants from the Malaysian Ministry of Science, Technology and Innovation (MOSTI), Malaysian Ministry of Higher Education (UM.C/HlR/MOHE/06) and Cancer Research Initiatives Foundation (CARIF). Additional controls were recruited by the Singapore Eye Research Institute, which was supported by a grant from the Biomedical Research Council (BMRC08/1/35/19<tel:08/1/35/ $19>/ 550)$, Singapore and the National medical Research Council, Singapore (NMRC/CG/SERI/2010). The NBCS was supported by grants from the Norwegian Research council (155218/V40, $175240 /$ S10 to ALBD, FUGE-NFR $181600 /$ V11 to VNK and a Swizz Bridge Award to ALBD). The NBHS was supported by NIH grant R01CA100374. Biological sample preparation was conducted the Survey and Biospecimen Shared Resource, which is supported by P30 CA68485. The OBCS was supported by research grants from the Finnish Cancer Foundation, the Sigrid Juselius Foundation, the Academy of Finland, the University of Oulu, and the Oulu University Hospital. The ORIGO study was supported by the Dutch Cancer Society (RUL 1997-1505) and the Biobanking and Biomolecular Resources Research Infrastructure (BBMRI-NL CP16). The PBCS was funded by Intramural Research Funds of the National Cancer Institute, Department of Health and Human Services, USA. pKARMA is a combination of the KARMA and LIBRO-1 studies. KARMA was supported by Märit and Hans Rausings Initiative against Breast Cancer. KARMA and LIBRO-1 were supported the Cancer Risk Prediction Center (CRisP; www.crispcenter.org), a Linnaeus Centre (Contract ID 70867902) financed by the Swedish Research Council. The RBCS was funded by the Dutch Cancer Society (DDHK 2004-3124, DDHK 20094318). SASBAC was supported by funding from the Agency for Science, Technology and Research of Singapore (A*STAR), the US National Institute of Health (NIH) and the Susan G Komen Breast Cancer Foundation. KC was financed by the Swedish Cancer Society (5128-B07-01PAF). The SBCGS was supported primarily by NIH grants R01CA64277, R01CA148667 and R37CA70867. Biological sample preparation was conducted the Survey and Biospecimen Shared Resource, which is supported by P30 CA68485. The SBCS was supported by Yorkshire Cancer Research S305PA, S299 and S295. Funding for the SCCS was provided by 
NIH grant R01 CA092447. The Arkansas Central Cancer Registry is fully funded by a grant from National Program of Cancer Registries, Centers for Disease Control and Prevention (CDC). Data on SCCS cancer cases from Mississippi were collected by the Mississippi Cancer Registry which participates in the National Program of Cancer Registries (NPCR) of the Centers for Disease Control and Prevention (CDC). The contents of this publication are solely the responsibility of the authors and do not necessarily represent the official views of the CDC or the Mississippi Cancer Registry. SEARCH is funded by a programme grant from Cancer Research UK (C490/A10124) and supported by the UK National Institute for Health Research Biomedical Research Centre at the University of Cambridge. SGBCC is funded by the National Medical Research Council start-up Grant and Centre Grant (NMRC/CG/NCIS/2010). The recruitment of controls by the Singapore Consortium of Cohort Studies-Multi-ethnic cohort (SCCS-MEC) was funded by the Biomedical Research Council (grant number: 05/1/21/19/425). SKKDKFZS is supported by the DKFZ. Katarzyna Jaworska is a fellow of International $\mathrm{PhD}$ program, Postgraduate School of Molecular Medicine, Warsaw Medical University, supported by the Polish Foundation of Science. The TNBCC was supported by the NIH grant (CA128978), the
Breast Cancer Research Foundation, Komen Foundation for the Cure, the Ohio State University Comprehensive Cancer Center, the Stefanie Spielman fund for Breast Cancer Research and a generous gift from the David F and Margaret T Grohne Family Foundation and the Ting Tsung and Wei Fong Chao Foundation. Part of the TNBCC (DEMOKRITOS) has been co-financed by the European Union (European Social Fund-ESF) and Greek national funds through the Operational Program 'Education and Lifelong Learning' of the National Strategic Reference Framework (NSRF)-Research Funding Program of the General Secretariat for Research \& Technology: ARISTEIA. The TWBCS is supported by the Institute of Biomedical Sciences, Academia Sinica and the National Science Council, Taiwan. The UKBGS is funded by Breakthrough Breast Cancer and the Institute of Cancer Research (ICR). ICR acknowledges NHS funding to the NIHR Biomedical Research Centre.

\section{CONFLICT OF INTEREST}

The authors declare no conflict of interest.

${ }^{1}$ Human Cancer Genetics Programme, Spanish National Cancer Research Centre (CNIO), Madrid, Spain; ${ }^{2}$ Department of Molecular, Cellular and Developmental Biology, Yale University, New Haven, CT, USA; ${ }^{3}$ Centre for Cancer Genetic Epidemiology, Department of Public Health and Primary Care, University of Cambridge, Cambridge, UK; ${ }^{4}$ Biostatistics Unit, IMDEA Food Institute, Madrid, Spain; ${ }^{5}$ Human Genotyping-CEGEN Unit, Spanish National Cancer Research Centre (CNIO), Madrid, Spain; ${ }^{6}$ CRUK Cambridge Institute, University of Cambridge, Cambridge, UK; ${ }^{7}$ Hospital Monte Naranco, Oviedo, Spain; ${ }^{8}$ Department of Pathology, Hospital Universitario La Paz, IdiPAZ (Hospital La Paz Institute for Health Research) Universidad Autonoma de Madrid, Madrid, Spain; ${ }^{9}$ Laboratory of Pathology and Oncology, Research Unit, Hospital Universitario La Paz, IdiPAZ, Madrid, Spain; ${ }^{10}$ Department of Molecular Medicine and Surgery, Karolinska Institutet, Stockholm, Sweden; ${ }^{11}$ Department of Oncology-Pathology, Karolinska Institutet, Stockholm, Sweden; ${ }^{12}$ Division of Genetics and Epidemiology, The Institute of Cancer Research, Sutton, UK; ${ }^{13}$ Division of Breast Cancer Research, The Institute of Cancer Research, London, UK; ${ }^{14}$ Breakthrough Breast Cancer Research Centre, Division of Breast Cancer Research, The Institute of Cancer Research, London, UK; ${ }^{15}$ Department of Preventive Medicine, Kyushu University Faculty of Medical Sciences, Fukuoka, Japan; ${ }^{16}$ Division of Epidemiology and Prevention, Aichi Cancer Center Research Institute, Nagoya, Japan; ${ }^{17}$ Department of Breast Oncology, Aichi Cancer Center Hospital, Nagoya, Japan; ${ }^{18}$ Peter MacCallum Cancer Centre, Melbourne, Victoria, Australia; ${ }^{19}$ QIMR Berghofer Institute of Medical Research, Brisbane, Queensland, Australia; ${ }^{20}$ Saw Swee Hock School of Public Health, Department of Surgery, Yong Loo Lin School of Medicine, National University of Singapore and National University Health System, Singapore, Singapore; ${ }^{21}$ Saw Swee Hock School of Public Health, National University of Singapore and National University Health System, Singapore, Singapore; ${ }^{22}$ Department of Surgery, Yong Loo Lin School of Medicine, National University of Singapore and National University Health System, Singapore, Singapore; ${ }^{23}$ Research Oncology, Division of Cancer Studies, Kings College London Guy's Hospital, London, UK; ${ }^{24}$ Wellcome Trust Centre for Human Genetics, University of Oxford, Oxford, UK; ${ }^{25}$ Oxford Biomedical Research Centre, University of Oxford, Oxford, UK; ${ }^{26}$ School of Medicine, Clinical Science Institute, National University of Ireland, Galway, UK; ${ }^{27}$ Department of Preventive Medicine, Seoul National University College of Medicine, Seoul, Korea; ${ }^{28}$ Department of Biomedical Sciences, Seoul National University Graduate School, Seoul, Korea; ${ }^{29}$ Department of Surgery, Seoul National University College of Medicine, Seoul, Korea; ${ }^{30}$ Centre for Epidemiology and Biostatistics, Melbourne School of Population and Global Health, University of Melbourne, Melbourne, Victoria, Australia; ${ }^{11}$ Department of Pathology, University of Melbourne, Melbourne, Victoria, Australia; ${ }^{32}$ Cancer Research Initiatives Foundation, Sime Darby Medical Centre, Subang Jaya, Malaysia; ${ }^{33}$ Breast Cancer Research Unit, University Malaya Cancer Research Institute, University Malaya Medical Centre, Kuala Lumpur, Malaysia; ${ }^{34}$ Singapore Eye Research Institute, National University of Singapore, Singapore; ${ }^{35}$ Dr Margarete FischerBosch Institute of Clinical Pharmacology, Stuttgart, Germany; ${ }^{36}$ University of Tübingen, Germany; ${ }^{37}$ Institute for Prevention and Occupational Medicine of the German Social Accident Insurance, Institute of the Ruhr-University Bochum (IPA), Germany; ${ }^{38}$ Molecular Genetics of Breast Cancer, Deutsches Krebsforschungszentrum (DKFZ), Heidelberg, Germany; ${ }^{39}$ Institute for Occupational Medicine and Maritime Medicine, University Medical Center Hamburg-Eppendorf, Germany; ${ }^{40}$ Institute of Pathology, Medical Faculty of the University of Bonn, Germany; ${ }^{41}$ Department of Internal Medicine, Evangelische Kliniken Bonn GmbH, Johanniter Krankenhaus, Bonn, Germany; ${ }^{42}$ Centre for Cancer Genetic Epidemiology, Department of Oncology, University of Cambridge, Cambridge, UK; ${ }^{43}$ Lunenfeld-Tanenbaum Research Institute, Mount Sinai Hospital, Toronto, Ontario, Canada; ${ }^{44}$ Department of Molecular Genetics, University of Toronto, Toronto, Ontario, Canada; ${ }^{45}$ Division of Epidemiology, Dalla Lana School of Public Health, University of Toronto, Toronto, Ontario, Canada; ${ }^{46}$ Ontario Cancer Genetics Network, Lunenfeld-Tanenbaum Research Institute, Toronto, Ontario, Canada; ${ }^{47}$ Netherlands Cancer Institute, Antoni van Leeuwenhoek Hospital, Amsterdam, The Netherlands; ${ }^{48}$ Department of Gynecology and Obstetrics, University Hospital Erlangen, Friedrich-Alexander University Erlangen-Nuremberg, Comprehensive Cancer Center Erlangen-EMN, Erlangen, Germany; ${ }^{49}$ David Geffen School of Medicine, Department of Medicine Division of Hematology and Oncology, University of California at Los Angeles, CA, USA; ${ }^{50}$ Institute of Human Genetics, University Hospital Erlangen, Friedrich-Alexander-Universität Erlangen-Nürnberg, 
Erlangen, Germany; ${ }^{51}$ Institute of Biomedical Sciences, Academia Sinica, Taipei, Taiwan; ${ }^{52}$ College of Public Health, China Medical University, Taichong, Taiwan; ${ }^{53}$ Tri-Service General Hospital, Taipei, Taiwan; ${ }^{54}$ Cancer Center, Kaohsiung Medical University Chung-Ho Memorial Hospital, Kaohsiung, Taiwan; ${ }^{55}$ Department of Surgery, Kaohsiung Medical University Chung-Ho Memorial Hospital, Kaohsiung, Taiwan; ${ }^{56}$ Department of Medicine, Vanderbilt University, Nashville, TN USA; ${ }^{57}$ Department of Preventive Medicine, Keck School of Medicine, University of Southern California, Los Angeles, CA, USA; ${ }^{58}$ CRUKNCR Sheffield Cancer Research Centre, Department of Oncology, University of Sheffield, Sheffield, UK; ${ }^{59}$ Institute of Population Health, University of Manchester, Manchester, UK; ${ }^{60}$ Division of Health Sciences, Warwick Medical School, Coventry, UK; ${ }^{61}$ Ministry of Public Health, Bangkok, Thailand; ${ }^{62}$ Division of Epidemiology, Department of Medicine, Vanderbilt University Medical Center, Nashville, TN, USA; ${ }^{3}$ Shanghai Center for Disease Control and Prevention, Shanghai, China; ${ }^{64}$ Shanghai Cancer Institute, Shanghai, China; ${ }^{65}$ Unit of Molecular Bases of Genetic Risk and Genetic Testing, Department of Preventive and Predictive Medicine, Fondazione IRCCS Istituto Nazionale dei Tumori (INT), Milan, Italy; ${ }^{66}$ IFOM, Fondazione Istituto FIRC di Oncologia Molecolare, Milan, Italy; ${ }^{67}$ Unit of Medical Genetics, Department of Preventive and Predictive Medicine, Fondazione IRCCS Istituto Nazionale dei Tumori (INT), Milan, Italy; ${ }^{68}$ Cogentech Cancer Genetic Test Laboratory, Milan, Italy; ${ }^{69}$ National Cancer Institute, Bangkok, Thailand; ${ }^{70}$ Genetic Susceptibility Group, International Agency for Research on Cancer, Lyon, France; ${ }^{71}$ Department of Laboratory Medicine and Pathology, Mayo Clinic, Rochester, MN, USA; ${ }^{72}$ Department of Molecular Virology, Immunology and Medical Genetics, Comprehensive Cancer Center, The Ohio State University, Columbus, OH, USA; ${ }^{73}$ Mayo Clinic, Rochester, MN, USA; ${ }^{74}$ Molecular Diagnostics Laboratory, INRASTES, National Centre for Scientific Research "Demokritos", Athens, Greece; ${ }^{75}$ Breakthrough Breast Cancer Research Centre, The Institute of Cancer Research, London, UK; ${ }^{76}$ London School of Hygiene and Tropical Medicine, London, UK; ${ }^{77}$ Department of Obstetrics and Gynecology, University of Heidelberg, Heidelberg, Germany; ${ }^{78}$ National Center for Tumor Diseases, University of Heidelberg, Heidelberg, Germany; ${ }^{79}$ Molecular Epidemiology Group, German Cancer Research Center (DKFZ), Heidelberg, Germany; ${ }^{80}$ Inserm (National Institute of Health and Medical Research), CESP (Center for Research in Epidemiology and Population Health), U1018, Environmental Epidemiology of Cancer, Villejuif, France; ${ }^{81}$ University Paris-Sud, UMRS 1018, Villejuif, France; ${ }^{82}$ Inserm (National Institute of Health and Medical Research), U775 Paris, France; ${ }^{83}$ Centre de Ressources Biologiques EPIGENETEC, Paris, France; ${ }^{84}$ Copenhagen General Population Study, Herlev University Hospital, University of Copenhagen, Copenhagen, Denmark; ${ }^{85}$ Department of Clinical Biochemistry, Herlev University Hospital, University of Copenhagen, Copenhagen, Denmark; ${ }^{86}$ Department of Breast Surgery, Herlev University Hospital, University of Copenhagen, Copenhagen, Denmark; ${ }^{87}$ Division of Clinical Epidemiology and Aging Research, German Cancer Research Center (DKFZ), Heidelberg, Germany; ${ }^{88}$ German Cancer Consortium (DKTK), Heidelberg, Germany; ${ }^{89}$ Saarland Cancer Registry, Saarbrücken, Germany; ${ }^{90}$ School of Medicine, Institute of Clinical Medicine, Pathology and Forensic Medicine, University of Eastern Finland, Kuopio, Finland; ${ }^{91}$ Biocenter Kuopio, University of Eastern Finland, Kuopio, Finland; ${ }^{92}$ Department of Clinical Pathology, Kuopio University Hospital, Kuopio, Finland; ${ }^{93}$ School of Medicine, Institute of Clinical Medicine, Oncology, University of Eastern Finland, Kuopio, Finland; ${ }^{94}$ Cancer Center, Kuopio University Hospital, Kuopio, Finland; ${ }^{95}$ Vesalius Research Center (VRC), VIB, Leuven, Belgium; ${ }^{96}$ Multidisciplinary Breast Center, University Hospital Gasthuisberg, Leuven, Belgium; ${ }^{97}$ Division of Cancer Epidemiology, German Cancer Research Center (DKFZ), Heidelberg, Germany; ${ }^{98}$ Institute for Medical Biometrics and Epidemiology, University Clinic Hamburg-Eppendorf, Hamburg, Germany; ${ }^{99}$ Department of Cancer Epidemiology/Clinical Cancer Registry, University Clinic Hamburg-Eppendorf, Hamburg, Germany; ${ }^{100}$ Department of Health Sciences Research, Mayo Clinic, Rochester, MN, USA; ${ }^{101}$ Cancer Epidemiology Centre, Cancer Council Victoria, Melbourne, Australia; ${ }^{102}$ University of Hawaii Cancer Center, Honolulu, HI, USA; ${ }^{103}$ Cancer Genomics Laboratory, Centre Hospitalier Universitaire de Quebec Research Center and Laval University, Quebec, Canada; ${ }^{104}$ Department of Medicine, McGill University, Montreal, Montreal, Quebec, Canada; ${ }^{105}$ Division of Clinical Epidemiology, McGill University Health Centre, Royal Victoria Hospital, Montreal, Quebec, Canada; ${ }^{106}$ Département de médecine sociale et préventive, Département de santé environnementale et santé au travail, Université de Montréal, Montreal, Quebec, Canada; ${ }^{107}$ Laboratory of Cancer Genetics and Tumor Biology, Department of Clinical Chemistry and Biocenter Oulu, University of Oulu, Oulu University Hospital, Oulu, Finland; ${ }^{108}$ Department of Oncology, Oulu University Hospital, University of Oulu, Oulu, Finland; ${ }^{109}$ Department of Surgery, Oulu University Hospital, University of Oulu, Oulu, Finland; ${ }^{110}$ Department of Human Genetics, Leiden University Medical Center, Leiden, The Netherlands; ${ }^{111}$ Department of Surgical Oncology, Leiden University Medical Center, Leiden, The Netherlands; ${ }^{112}$ Department of Medical Oncology, Family Cancer Clinic, Erasmus University Medical Centre, Rotterdam, The Netherlands; ${ }^{113}$ Division of Cancer Epidemiology and Genetics, National Cancer Institute, Rockville, MD, USA; ${ }^{114}$ Division of Genetics and Epidemiology, Institute of Cancer Research and Breakthrough Breast Cancer Research Centre, London, UK; ${ }^{115}$ Department of Cancer Epidemiology and Prevention, M. Sklodowska-Curie Memorial Cancer Center \& Institute of Oncology, Warsaw, Poland; ${ }^{116}$ Department of Medical Epidemiology and Biostatistics, Karolinska Institutet, Stockholm, Sweden; ${ }^{117}$ Department of Clinical Genetics, Family Cancer Clinic, Erasmus University Medical Center, Rotterdam, The Netherlands; ${ }^{118}$ Department of Surgical Oncology, Family Cancer Clinic, Erasmus University Medical Centre, Rotterdam, The Netherlands; ${ }^{119}$ Human Genetics Division, Genome Institute of Singapore, Singapore, Singapore; ${ }^{120}$ Department of Genetics and Pathology, Pomeranian Medical University, Szczecin, Poland; ${ }^{121}$ Department of Obstetrics and Gynecology, University of Helsinki and Helsinki University Central Hospital, Helsinki, Finland; ${ }^{122}$ Department of Clinical Genetics, Helsinki University Central Hospital, Helsinki, Finland; ${ }^{123}$ Department of Oncology, Helsinki University Central Hospital, Helsinki, Finland; ${ }^{124}$ Department of Obstetrics and Gynaecology, Hannover Medical School, Hannover, Germany; ${ }^{125}$ Department of Radiation Oncology, Hannover Medical School, Hannover, Germany; ${ }^{126}$ Servicio de Cirugía General y Especialidades, Hospital Monte Naranco, Oviedo, Spain; ${ }^{127}$ Servicio de Oncología Médica, Hospital Universitario La Paz, Madrid, Spain 


\section{REFERENCES}

Ahmed S, Thomas G, Ghoussaini M, Healey CS, Humphreys MK, Platte R, Morrison J, Maranian M, Pooley KA, Luben R, Eccles D, Evans DG, Fletcher O, Johnson N, dos Santos Silva I, Peto J, Stratton MR, Rahman N, Jacobs K, Prentice R, Anderson GL, Rajkovic A, Curb JD, Ziegler RG, Berg CD, Buys SS, McCarty CA, Feigelson HS, Calle EE, Thun MJ, Diver WR, Bojesen S, Nordestgaard BG, Flyger H, Dork T, Schurmann P, Hillemanns P, Karstens JH, Bogdanova NV, Antonenkova NN, Zalutsky IV, Bermisheva M, Fedorova S, Khusnutdinova E, Kang D, Yoo KY, Noh DY, Ahn SH, Devilee P, van Asperen CJ, Tollenaar RA, Seynaeve C, Garcia-Closas M, Lissowska J, Brinton L, Peplonska B, Nevanlinna H, Heikkinen T, Aittomaki K, Blomqvist C, Hopper JL, Southey MC, Smith L, Spurdle AB, Schmidt MK, Broeks A, van Hien RR, Cornelissen S, Milne RL, Ribas G, Gonzalez-Neira A, Benitez J, Schmutzler RK, Burwinkel B, Bartram CR, Meindl A, Brauch H, Justenhoven C, Hamann U, Chang-Claude J, Hein R, Wang-Gohrke S, Lindblom A, Margolin S, Mannermaa A, Kosma VM, Kataja V, Olson JE, Wang X, Fredericksen Z, Giles GG, Severi G, Baglietto L, English DR, Hankinson SE, Cox DG, Kraft P, Vatten LJ, Hveem K, Kumle M, Sigurdson A, Doody M, Bhatti P, Alexander BH, Hooning MJ, van den Ouweland AM, Oldenburg RA, Schutte M, Hall P, Czene K, Liu J, Li Y, Cox A, Elliott G, Brock I, Reed MW, Shen CY, Yu JC, Hsu GC, Chen ST, Anton-Culver H, Ziogas A, Andrulis IL, Knight JA, Beesley J, Goode EL, Couch F, Chenevix-Trench G, Hoover RN, Ponder BA, Hunter DJ, Pharoah PD, Dunning AM, Chanock SJ, Easton DF (2009) Newly discovered breast cancer susceptibility loci on 3p24 and 17q23.2. Nat Genet 41: 585-590.

Antoniou A, Pharoah PD, Narod S, Risch HA, Eyfjord JE, Hopper JL, Loman N, Olsson H, Johannsson O, Borg A, Pasini B, Radice P, Manoukian S, Eccles DM, Tang N, Olah E, Anton-Culver H, Warner E, Lubinski J, Gronwald J, Gorski B, Tulinius H, Thorlacius S, Eerola H, Nevanlinna H, Syrjakoski K, Kallioniemi OP, Thompson D, Evans C, Peto J, Lalloo F, Evans DG, Easton DF (2003) Average risks of breast and ovarian cancer associated with BRCA1 or BRCA2 mutations detected in case Series unselected for family history: a combined analysis of 22 studies. Am J Hum Genet 72: 1117-1130.

Antoniou AC, Wang X, Fredericksen ZS, McGuffog L, Tarrell R, Sinilnikova OM, Healey S, Morrison J, Kartsonaki C, Lesnick T, Ghoussaini M, Barrowdale D, Peock S, Cook M, Oliver C, Frost D, Eccles D, Evans DG, Eeles R, Izatt L, Chu C, Douglas F, Paterson J, Stoppa-Lyonnet D, Houdayer C, Mazoyer S, Giraud S, Lasset C, Remenieras A, Caron O, Hardouin A, Berthet P, Hogervorst FB, Rookus MA, Jager A, van den Ouweland A, Hoogerbrugge N, van der Luijt RB, Meijers-Heijboer H, Gomez Garcia EB, Devilee P, Vreeswijk MP, Lubinski J, Jakubowska A, Gronwald J, Huzarski T, Byrski T, Gorski B, Cybulski C, Spurdle AB, Holland H, Goldgar DE, John EM, Hopper JL, Southey M, Buys SS, Daly MB, Terry MB, Schmutzler RK, Wappenschmidt B, Engel C, Meindl A, Preisler-Adams S, Arnold N, Niederacher D, Sutter C, Domchek SM, Nathanson KL, Rebbeck T, Blum JL, Piedmonte M, Rodriguez GC, Wakeley K, Boggess JF, Basil J, Blank SV, Friedman E, Kaufman B, Laitman Y, Milgrom R, Andrulis IL, Glendon G, Ozcelik H, Kirchhoff T, Vijai J, Gaudet MM, Altshuler D, Guiducci C, Loman N, Harbst K, Rantala J, Ehrencrona H, Gerdes AM, Thomassen M, Sunde L, Peterlongo P, Manoukian S, Bonanni B, Viel A, Radice P, Caldes T, de la Hoya M, Singer CF, Fink-Retter A, Greene MH, Mai PL, Loud JT, Guidugli L, Lindor NM, Hansen TV, Nielsen FC, Blanco I, Lazaro C, Garber J, Ramus SJ, Gayther SA, Phelan C, Narod S, Szabo CI, Benitez J, Osorio A, Nevanlinna H, Heikkinen T, Caligo MA, Beattie MS, Hamann U, Godwin AK, Montagna M, Casella C, Neuhausen SL, Karlan BY, Tung N, Toland AE, Weitzel J, Olopade O, Simard J, Soucy P, Rubinstein WS, Arason A, Rennert G, Martin NG, Montgomery GW, Chang-Claude J, Flesch-Janys D, Brauch H, Severi G, Baglietto L, Cox A, Cross SS, Miron P, Gerty SM, Tapper W, Yannoukakos D, Fountzilas G, Fasching PA, Beckmann MW, Dos Santos Silva I, Peto J, Lambrechts D, Paridaens R, Rudiger T, Forsti A, Winqvist R, Pylkas K, Diasio RB, Lee AM, Eckel-Passow J, Vachon C, Blows F, Driver K, Dunning A, Pharoah PP, Offit K, Pankratz VS, Hakonarson H, Chenevix-Trench G, Easton DF, Couch FJ (2010) A locus on 19p13 modifies risk of breast cancer in BRCA1 mutation carriers and is associated with hormone receptor-negative breast cancer in the general population. Nat Genet 42: 885-892.

Aulchenko YS, Ripke S, Isaacs A, van Duijn CM (2007) GenABEL: an R library for genome-wide association analysis. Bioinformatics 23: 1294-1296.
Barrett JC, Fry B, Maller J, Daly MJ (2005) Haploview: analysis and visualization of LD and haplotype maps. Bioinformatics 21: 263-265.

Bojesen SE, Pooley KA, Johnatty SE, Beesley J, Michailidou K, Tyrer JP, Edwards SL, Pickett HA, Shen HC, Smart CE, Hillman KM, Mai PL, Lawrenson K, Stutz MD, Lu Y, Karevan R, Woods N, Johnston RL, French JD, Chen X, Weischer M, Nielsen SF, Maranian MJ, Ghoussaini M, Ahmed S, Baynes C, Bolla MK, Wang Q, Dennis J, McGuffog L, Barrowdale D, Lee A, Healey S, Lush M, Tessier DC, Vincent D, Bacot F, Vergote I, Lambrechts S, Despierre E, Risch HA, Gonzalez-Neira A, Rossing MA, Pita G, Doherty JA, Alvarez N, Larson MC, Fridley BL, Schoof N, Chang-Claude J, Cicek MS, Peto J, Kalli KR, Broeks A, Armasu SM, Schmidt MK, Braaf LM, Winterhoff B, Nevanlinna H, Konecny GE, Lambrechts D, Rogmann L, Guenel P, Teoman A, Milne RL, Garcia JJ, Cox A, Shridhar V, Burwinkel B, Marme F, Hein R, Sawyer EJ, Haiman CA, Wang-Gohrke S, Andrulis IL, Moysich KB, Hopper JL, Odunsi K, Lindblom A, Giles GG, Brenner H, Simard J, Lurie G, Fasching PA, Carney ME, Radice P, Wilkens LR, Swerdlow A, Goodman MT, Brauch H, Garcia-Closas M, Hillemanns P, Winqvist R, Durst M, Devilee P, Runnebaum I, Jakubowska A, Lubinski J, Mannermaa A, Butzow R, Bogdanova NV, Dork T, Pelttari LM, Zheng W, Leminen A, Anton-Culver H, Bunker CH, Kristensen V, Ness RB, Muir K, Edwards R, Meindl A, Heitz F, Matsuo K, du Bois A, Wu AH, Harter P, Teo SH, Schwaab I, Shu XO, Blot W, Hosono S, Kang D, Nakanishi T, Hartman M, Yatabe Y, Hamann U, Karlan BY, Sangrajrang S, Kjaer SK, Gaborieau V, Jensen A, Eccles D, Hogdall E, Shen CY, Brown J, Woo YL, Shah M, Azmi MA, Luben R, Omar SZ, Czene K, Vierkant RA, Nordestgaard BG, Flyger H, Vachon C, Olson JE, Wang X, Levine DA, Rudolph A, Weber RP, Flesch-Janys D, Iversen E, Nickels S,

Schildkraut JM, Silva Idos S, Cramer DW, Gibson L, Terry KL, Fletcher O, Vitonis AF, van der Schoot CE, Poole EM, Hogervorst FB, Tworoger SS, Liu J, Bandera EV, Li J, Olson SH, Humphreys K, Orlow I, Blomqvist C, Rodriguez-Rodriguez L, Aittomaki K, Salvesen HB, Muranen TA, Wik E, Brouwers B, Krakstad C, Wauters E, Halle MK, Wildiers H, Kiemeney LA, Mulot C, Aben KK, Laurent-Puig P, Altena AM, Truong T, Massuger LF, Benitez J, Pejovic T, Perez JI, Hoatlin M, Zamora MP, Cook LS, Balasubramanian SP, Kelemen LE, Schneeweiss A, Le ND, Sohn C, Brooks-Wilson A, Tomlinson I, Kerin MJ, Miller N, Cybulski C, Henderson BE, Menkiszak J, Schumacher F, Wentzensen N, Le Marchand L, Yang HP, Mulligan AM, Glendon G, Engelholm SA, Knight JA, Hogdall CK, Apicella C, Gore M, Tsimiklis H, Song H, Southey MC, Jager A, den Ouweland AM, Brown R, Martens JW, Flanagan JM, Kriege M, Paul J, Margolin S, Siddiqui N, Severi G, Whittemore AS, Baglietto L, McGuire V, Stegmaier C, Sieh W, Muller H, Arndt V, Labreche F, Gao YT, Goldberg MS, Yang G, Dumont M, McLaughlin JR, Hartmann A, Ekici AB, Beckmann MW, Phelan CM, Lux MP, Permuth-Wey J, Peissel B, Sellers TA, Ficarazzi F, Barile M, Ziogas A, Ashworth A, Gentry-Maharaj A, Jones M, Ramus SJ, Orr N, Menon U, Pearce CL, Bruning T, Pike MC, Ko YD, Lissowska J, Figueroa J, Kupryjanczyk J, Chanock SJ, Dansonka-Mieszkowska A, Jukkola-Vuorinen A, Rzepecka IK, Pylkas K, Bidzinski M, Kauppila S, Hollestelle A, Seynaeve C, Tollenaar RA, Durda K, Jaworska K, Hartikainen JM, Kosma VM, Kataja V, Antonenkova NN, Long J, Shrubsole M, Deming-Halverson S, Lophatananon A, Siriwanarangsan P, Stewart-Brown S, Ditsch N, Lichtner P, Schmutzler RK, Ito H, Iwata H, Tajima K, Tseng CC, Stram DO, van den Berg D, Yip CH, Ikram MK, Teh YC, Cai H, Lu W, Signorello LB, Cai Q, Noh DY, Yoo KY, Miao H, Iau PT, Teo YY, McKay J, Shapiro C, Ademuyiwa F, Fountzilas G, Hsiung CN, Yu JC, Hou MF, Healey CS, Luccarini C, Peock S, Stoppa-Lyonnet D, Peterlongo P, Rebbeck TR, Piedmonte M, Singer CF, Friedman E, Thomassen M, Offit K, Hansen TV, Neuhausen SL, Szabo CI, Blanco I, Garber J, Narod SA, Weitzel JN, Montagna M, Olah E, Godwin AK, Yannoukakos D, Goldgar DE, Caldes T, Imyanitov EN, Tihomirova L, Arun BK, Campbell I, Mensenkamp AR, van Asperen CJ, van Roozendaal KE, Meijers-Heijboer H, Collee JM, Oosterwijk JC, Hooning MJ, Rookus MA, van der Luijt RB, Os TA, Evans DG, Frost D, Fineberg E, Barwell J, Walker L, Kennedy MJ, Platte R, Davidson R, Ellis SD, Cole T, Bressac-de Paillerets B, Buecher B, Damiola F, Faivre L, Frenay M, Sinilnikova OM, Caron O, Giraud S, Mazoyer S, Bonadona V, Caux-Moncoutier V, Toloczko-Grabarek A, Gronwald J, Byrski T, Spurdle AB, Bonanni B, Zaffaroni D, Giannini G, Bernard L, Dolcetti R, Manoukian S, Arnold N, Engel C, Deissler H, Rhiem K, Niederacher D, Plendl H, Sutter C, Wappenschmidt B, Borg A, Melin B, Rantala J, Soller M, Nathanson KL, Domchek SM, Rodriguez GC, Salani R, 
Kaulich DG, Tea MK, Paluch SS, Laitman Y, Skytte AB, Kruse TA, Jensen UB, Robson M, Gerdes AM, Ejlertsen B, Foretova L, Savage SA, Lester J, Soucy P, Kuchenbaecker KB, Olswold C, Cunningham JM, Slager S, Pankratz VS, Dicks E, Lakhani SR, Couch FJ, Hall P, Monteiro AN, Gayther SA, Pharoah PD, Reddel RR, Goode EL, Greene MH, Easton DF, Berchuck A, Antoniou AC, Chenevix-Trench G, Dunning AM (2013) Multiple independent variants at the TERT locus are associated with telomere length and risks of breast and ovarian cancer. Nat Genet 45: 371-384, 384. e1-e2.

Cai Q, Long J, Lu W, Qu S, Wen W, Kang D, Lee JY, Chen K, Shen H, Shen CY, Sung H, Matsuo K, Haiman CA, Khoo US, Ren Z, Iwasaki M, Gu K, Xiang YB, Choi JY, Park SK, Zhang L, Hu Z, Wu PE, Noh DY, Tajima K, Henderson BE, Chan KY, Su F, Kasuga Y, Wang W, Cheng JR, Yoo KY, Zheng H, Liu Y, Shieh YL, Kim SW, Lee JW, Iwata H, Le Marchand L, Chan SY, Xie X, Tsugane S, Lee MH, Wang S, Li G, Levy S, Huang B, Shi J, Delahanty R, Zheng Y, Li C, Gao YT, Shu XO, Zheng W (2011) Genome-wide association study identifies breast cancer risk variant at 10q21.2: results from the Asia Breast Cancer Consortium. Hum Mol Genet 20: 4991-4999.

Chen GJ, Forough R (2006) Fibroblast growth factors, fibroblast growth factor receptors, diseases, and drugs. Recent Pat Cardiovasc Drug Discov 1: 211-224.

Easton DF, Pooley KA, Dunning AM, Pharoah PD, Thompson D, Ballinger DG, Struewing JP, Morrison J, Field H, Luben R, Wareham N, Ahmed S, Healey CS, Bowman R, Meyer KB, Haiman CA, Kolonel LK, Henderson BE, Le Marchand L, Brennan P, Sangrajrang S, Gaborieau V, Odefrey F, Shen CY, Wu PE, Wang HC, Eccles D, Evans DG, Peto J, Fletcher O, Johnson N, Seal S, Stratton MR, Rahman N, Chenevix-Trench G, Bojesen SE, Nordestgaard BG, Axelsson CK, Garcia-Closas M, Brinton L, Chanock S, Lissowska J, Peplonska B, Nevanlinna H, Fagerholm R, Eerola H, Kang D, Yoo KY, Noh DY, Ahn SH, Hunter DJ, Hankinson SE, Cox DG, Hall P, Wedren S, Liu J, Low YL, Bogdanova N, Schurmann P, Dork T, Tollenaar RA, Jacobi CE, Devilee P, Klijn JG, Sigurdson AJ, Doody MM, Alexander BH, Zhang J, Cox A, Brock IW, MacPherson G, Reed MW, Couch FJ, Goode EL, Olson JE, Meijers-Heijboer H, van den Ouweland A, Uitterlinden A, Rivadeneira F, Milne RL, Ribas G, Gonzalez-Neira A, Benitez J, Hopper JL, McCredie M, Southey M, Giles GG, Schroen C, Justenhoven C, Brauch H, Hamann U, Ko YD, Spurdle AB, Beesley J, Chen X, Mannermaa A, Kosma VM, Kataja V, Hartikainen J, Day NE, Cox DR, Ponder BA (2007) Genome-wide association study identifies novel breast cancer susceptibility loci. Nature 447: 1087-1093.

Eswarakumar VP, Lax I, Schlessinger J (2005) Cellular signaling by fibroblast growth factor receptors. Cytokine Growth Factor Rev 16: 139-149.

Fletcher O, Johnson N, Orr N, Hosking FJ, Gibson LJ, Walker K, Zelenika D, Gut I, Heath S, Palles C, Coupland B, Broderick P, Schoemaker M, Jones M, Williamson J, Chilcott-Burns S, Tomczyk K, Simpson G, Jacobs KB, Chanock SJ, Hunter DJ, Tomlinson IP, Swerdlow A, Ashworth A, Ross G, dos Santos Silva I, Lathrop M, Houlston RS, Peto J (2011) Novel breast cancer susceptibility locus at 9q31.2: results of a genome-wide association study. J Natl Cancer Inst 103: 425-435.

Garcia-Closas M, Couch FJ, Lindstrom S, Michailidou K, Schmidt MK, Brook MN, Orr N, Rhie SK, Riboli E, Feigelson HS, Le Marchand L, Buring JE, Eccles D, Miron P, Fasching PA, Brauch H, Chang-Claude J, Carpenter J, Godwin AK, Nevanlinna H, Giles GG, Cox A, Hopper JL, Bolla MK, Wang Q, Dennis J, Dicks E, Howat WJ, Schoof N, Bojesen SE, Lambrechts D, Broeks A, Andrulis IL, Guenel P, Burwinkel B, Sawyer EJ, Hollestelle A, Fletcher O, Winqvist R, Brenner H, Mannermaa A, Hamann U, Meindl A, Lindblom A, Zheng W, Devillee P, Goldberg MS, Lubinski J, Kristensen V, Swerdlow A, Anton-Culver H, Dork T, Muir K, Matsuo K, Wu AH, Radice P, Teo SH, Shu XO, Blot W, Kang D, Hartman M, Sangrajrang S, Shen CY, Southey MC, Park DJ, Hammet F, Stone J, Veer LJ, Rutgers EJ, Lophatananon A, Stewart-Brown S, Siriwanarangsan P, Peto J, Schrauder MG, Ekici AB, Beckmann MW, Dos Santos Silva I, Johnson N, Warren H, Tomlinson I, Kerin MJ, Miller N, Marme F, Schneeweiss A, Sohn C, Truong T, Laurent-Puig P, Kerbrat P, Nordestgaard BG, Nielsen SF, Flyger H, Milne RL, Perez JI, Menendez P, Muller H, Arndt V, Stegmaier C, Lichtner P, Lochmann M, Justenhoven C, Ko YD, Muranen TA, Aittomaki K, Blomqvist C, Greco D, Heikkinen T, Ito H, Iwata H, Yatabe Y, Antonenkova NN, Margolin S, Kataja V, Kosma VM, Hartikainen JM, Balleine R, Tseng CC, Berg DV, Stram DO, Neven P, Dieudonne AS, Leunen K, Rudolph A, Nickels S, Flesch-Janys D, Peterlongo P, Peissel B, Bernard L, Olson JE, Wang X,
Stevens K, Severi G, Baglietto L, McLean C, Coetzee GA, Feng Y, Henderson BE, Schumacher F, Bogdanova NV, Labreche F, Dumont M, Yip CH, Taib NA, Cheng CY, Shrubsole M, Long J, Pylkas K, Jukkola-Vuorinen A, Kauppila S, Knight JA, Glendon G, Mulligan AM, Tollenaar RA, Seynaeve CM, Kriege M, Hooning MJ, van den Ouweland AM, van Deurzen CH, Lu W, Gao YT, Cai H, Balasubramanian SP, Cross SS, Reed MW, Signorello L, Cai Q, Shah M, Miao H, Chan CW, Chia KS, Jakubowska A, Jaworska K, Durda K, Hsiung CN, Wu PE, Yu JC, Ashworth A, Jones M, Tessier DC, Gonzalez-Neira A, Pita G, Alonso MR, Vincent D, Bacot F, Ambrosone CB, Bandera EV, John EM, Chen GK, Hu JJ, Rodriguez-Gil JL, Bernstein L, Press MF, Ziegler RG, Millikan RM, Deming-Halverson SL, Nyante S, Ingles SA, Waisfisz Q, Tsimiklis $\mathrm{H}$, Makalic E, Schmidt D, Bui M, Gibson L, Muller-Myhsok B, Schmutzler RK, Hein R, Dahmen N, Beckmann L, Aaltonen K, Czene K, Irwanto A, Liu J, Turnbull C, Rahman N, Meijers-Heijboer H, Uitterlinden AG, Rivadeneira F, Olswold C, Slager S, Pilarski R, Ademuyiwa F, Konstantopoulou I, Martin NG, Montgomery GW, Slamon DJ, Rauh C, Lux MP, Jud SM, Bruning T, Weaver J, Sharma P, Pathak H, Tapper W, Gerty S, Durcan L, Trichopoulos D, Tumino R, Peeters PH, Kaaks R, Campa D, Canzian F, Weiderpass E, Johansson M, Khaw KT, Travis R, Clavel-Chapelon F, Kolonel LN, Chen C, Beck A, Hankinson SE, Berg CD, Hoover RN, Lissowska J, Figueroa JD, Chasman DI, Gaudet MM, Diver WR, Willett WC, Hunter DJ, Simard J, Benitez J, Dunning AM, Sherman ME, Chenevix-Trench G, Chanock SJ, Hall P, Pharoah PD, Vachon C, Easton DF, Haiman CA, Kraft P (2013) Genome-wide association studies identify four ER negative-specific breast cancer risk loci. Nat Genet 45: 392-398, 398. e1-e2.

Garcia-Closas M, Hall P, Nevanlinna H, Pooley K, Morrison J, Richesson DA, Bojesen SE, Nordestgaard BG, Axelsson CK, Arias JI, Milne RL, Ribas G, Gonzalez-Neira A, Benitez J, Zamora P, Brauch H, Justenhoven C, Hamann U, Ko YD, Bruening T, Haas S, Dork T, Schurmann P, Hillemanns P, Bogdanova N, Bremer M, Karstens JH, Fagerholm R, Aaltonen K, Aittomaki K, von Smitten K, Blomqvist C, Mannermaa A, Uusitupa M, Eskelinen M, Tengstrom M, Kosma VM, Kataja V, Chenevix-Trench G, Spurdle AB, Beesley J, Chen X, Devilee P, van Asperen CJ, Jacobi CE, Tollenaar RA, Huijts PE, Klijn JG, Chang-Claude J, Kropp S, Slanger T, Flesch-Janys D, Mutschelknauss E, Salazar R, Wang-Gohrke S, Couch F, Goode EL, Olson JE, Vachon C, Fredericksen ZS, Giles GG, Baglietto L, Severi G, Hopper JL, English DR, Southey MC, Haiman CA, Henderson BE, Kolonel LN, Le Marchand L, Stram DO, Hunter DJ, Hankinson SE, Cox DG, Tamimi R, Kraft P, Sherman ME, Chanock SJ, Lissowska J, Brinton LA, Peplonska B, Hooning MJ, Meijers-Heijboer H, Collee JM, van den Ouweland A, Uitterlinden AG, Liu J, Lin LY, Yuqing L, Humphreys K, Czene K, Cox A, Balasubramanian SP, Cross SS, Reed MW, Blows F, Driver K, Dunning A, Tyrer J, Ponder BA, Sangrajrang S, Brennan P, McKay J, Odefrey F, Gabrieau V, Sigurdson A, Doody M, Struewing JP, Alexander B, Easton DF, Pharoah PD (2008) Heterogeneity of breast cancer associations with five susceptibility loci by clinical and pathological characteristics. PLoS Genet 4: e1000054.

Ghoussaini M, Fletcher O, Michailidou K, Turnbull C, Schmidt MK, Dicks E, Dennis J, Wang Q, Humphreys MK, Luccarini C, Baynes C, Conroy D, Maranian M, Ahmed S, Driver K, Johnson N, Orr N, dos Santos Silva I, Waisfisz Q, Meijers-Heijboer H, Uitterlinden AG, Rivadeneira F, Hall P, Czene K, Irwanto A, Liu J, Nevanlinna H, Aittomaki K, Blomqvist C, Meindl A, Schmutzler RK, Muller-Myhsok B, Lichtner P, Chang-Claude J, Hein R, Nickels S, Flesch-Janys D, Tsimiklis H, Makalic E, Schmidt D, Bui M, Hopper JL, Apicella C, Park DJ, Southey M, Hunter DJ, Chanock SJ, Broeks A, Verhoef S, Hogervorst FB, Fasching PA, Lux MP, Beckmann MW, Ekici AB, Sawyer E, Tomlinson I, Kerin M, Marme F, Schneeweiss A, Sohn C, Burwinkel B, Guenel P, Truong T, Cordina-Duverger E, Menegaux F, Bojesen SE, Nordestgaard BG, Nielsen SF, Flyger H, Milne RL, Alonso MR, Gonzalez-Neira A, Benitez J, Anton-Culver H, Ziogas A, Bernstein L, Dur CC, Brenner H, Muller H, Arndt V, Stegmaier C, Justenhoven C, Brauch H, Bruning T, Wang-Gohrke S, Eilber U, Dork T, Schurmann P, Bremer M, Hillemanns P, Bogdanova NV, Antonenkova NN, Rogov YI, Karstens JH, Bermisheva M, Prokofieva D, Khusnutdinova E, Lindblom A, Margolin S, Mannermaa A, Kataja V, Kosma VM, Hartikainen JM, Lambrechts D, Yesilyurt BT, Floris G, Leunen K, Manoukian S, Bonanni B, Fortuzzi S, Peterlongo P, Couch FJ, Wang X, Stevens K, Lee A, Giles GG, Baglietto L, Severi G, McLean C, Alnaes GG, Kristensen V, Borrensen-Dale AL, John EM, Miron A, Winqvist R, Pylkas K, Jukkola-Vuorinen A, Kauppila S, 
Andrulis IL, Glendon G, Mulligan AM, Devilee P, van Asperen CJ, Tollenaar RA, Seynaeve C, Figueroa JD, Garcia-Closas M, Brinton L, Lissowska J, Hooning MJ, Hollestelle A, Oldenburg RA, van den Ouweland AM, Cox A, Reed MW, Shah M, Jakubowska A, Lubinski J, Jaworska K, Durda K, Jones M, Schoemaker M, Ashworth A, Swerdlow A, Beesley J, Chen X, Muir KR, Lophatananon A, Rattanamongkongul S, Chaiwerawattana A, Kang D, Yoo KY, Noh DY, Shen CY, Yu JC, Wu PE, Hsiung CN, Perkins A, Swann R, Velentzis L, Eccles DM, Tapper WJ, Gerty SM, Graham NJ, Ponder BA, Chenevix-Trench G, Pharoah PD, Lathrop M, Dunning AM, Rahman N, Peto J, Easton DF (2012) Genome-wide association analysis identifies three new breast cancer susceptibility loci. Nat Genet 44: 312-318.

Haiman CA, Chen GK, Vachon CM, Canzian F, Dunning A, Millikan RC, Wang X, Ademuyiwa F, Ahmed S, Ambrosone CB, Baglietto L, Balleine R, Bandera EV, Beckmann MW, Berg CD, Bernstein L, Blomqvist C, Blot WJ, Brauch H, Buring JE, Carey LA, Carpenter JE, Chang-Claude J, Chanock SJ, Chasman DI, Clarke CL, Cox A, Cross SS, Deming SL, Diasio RB, Dimopoulos AM, Driver WR, Dunnebier T, Durcan L, Eccles D, Edlund CK, Ekici AB, Fasching PA, Feigelson HS, Flesch-Janys D, Fostira F, Forsti A, Fountzilas G, Gerty SM, Giles GG, Godwin AK, Goodfellow P, Graham N, Greco D, Hamann U, Hankinson SE, Hartmann A, Hein R, Heinz J, Holbrook A, Hoover RN, Hu JJ, Hunter DJ, Ingles SA, Irwanto A, Ivanovich J, John EM, Johnson N, Jukkola-Vuorinen A, Kaaks R, Ko YD, Kolonel LN, Konstantopoulou I, Kosma VM, Kulkarni S, Lambrechts D, Lee AM, Marchand LL, Lesnick T, Liu J, Lindstrom S, Mannermaa A, Margolin S, Martin NG, Miron P, Montgomery GW, Nevanlinna H, Nickels S, Nyante S, Olswold C, Palmer J, Pathak H, Pectasides D, Perou CM, Peto J, Pharoah PD, Pooler LC, Press MF, Pylkas K, Rebbeck TR, Rodriguez-Gil JL, Rosenberg L, Ross E, Rudiger T, Silva Idos S, Sawyer E, Schmidt MK, Schulz-Wendtland R, Schumacher F, Severi G, Sheng X, Signorello LB, Sinn HP, Stevens KN, Southey MC, Tapper WJ, Tomlinson I, Hogervorst FB, Wauters E, Weaver J, Wildiers H, Winqvist R, Van Den Berg D, Wan P, Xia LY, Yannoukakos D, Zheng W, Ziegler RG, Siddiq A, Slager SL, Stram DO, Easton D, Kraft P, Henderson BE, Couch FJ (2011) A common variant at the TERT-CLPTM1L locus is associated with estrogen receptor-negative breast cancer. Nat Genet 43: $1210-1214$.

Haldane JBS (1954) An exact test for randomness of mating. J Genet 52: 631-635.

Higgins JP, Thompson SG (2002) Quantifying heterogeneity in a meta-analysis. Stat Med 21: 1539-1558.

Huijts PE, van Dongen M, de Goeij MC, van Moolenbroek AJ, Blanken F, Vreeswijk MP, de Kruijf EM, Mesker WE, van Zwet EW, Tollenaar RA, Smit VT, van Asperen CJ, Devilee P (2011) Allele-specific regulation of FGFR2 expression is cell type-dependent and may increase breast cancer risk through a paracrine stimulus involving FGF10. Breast Cancer Res 13: R72.

Hunter DJ, Kraft P, Jacobs KB, Cox DG, Yeager M, Hankinson SE, Wacholder S, Wang Z, Welch R, Hutchinson A, Wang J, Yu K, Chatterjee N, Orr N, Willett WC, Colditz GA, Ziegler RG, Berg CD, Buys SS, McCarty CA, Feigelson HS, Calle EE, Thun MJ, Hayes RB, Tucker M, Gerhard DS, Fraumeni Jr JF, Hoover RN, Thomas G, Chanock SJ (2007) A genome-wide association study identifies alleles in FGFR2 associated with risk of sporadic postmenopausal breast cancer. Nat Genet 39: 870-874.

Li J, Ji L (2005) Adjusting multiple testing in multilocus analyses using the eigenvalues of a correlation matrix. Heredity (Edinb) 95: 221-227.

Meijers-Heijboer H, van den Ouweland A, Klijn J, Wasielewski M, de Snoo A, Oldenburg R, Hollestelle A, Houben M, Crepin E, van Veghel-Plandsoen M, Elstrodt F, van Duijn C, Bartels C, Meijers C, Schutte M, McGuffog L, Thompson D, Easton D, Sodha N, Seal S, Barfoot R, Mangion J, Chang-Claude J, Eccles D, Eeles R, Evans DG, Houlston R, Murday V, Narod S, Peretz T, Peto J, Phelan C, Zhang HX, Szabo C, Devilee P, Goldgar D, Futreal PA, Nathanson KL, Weber B, Rahman N, Stratton MR (2002) Low-penetrance susceptibility to breast cancer due to CHEK2 $\left({ }^{*}\right)$ 1100 delC in noncarriers of BRCA1 or BRCA2 mutations. Nat Genet 31: $55-59$.

Meyer KB, Maia AT, O’Reilly M, Teschendorff AE, Chin SF, Caldas C, Ponder BA (2008) Allele-specific up-regulation of FGFR2 increases susceptibility to breast cancer. PLoS Biol 6: e108.

Meyer KB, O’Reilly M, Michailidou K, Carlebur S, Edwards SL, French JD, Prathalingham R, Dennis J, Bolla MK, Wang Q, de Santiago I, Hopper JL, Tsimiklis H, Apicella C, Southey MC, Schmidt MK, Broeks A, Van 't Veer LJ, Hogervorst FB, Muir K, Lophatananon A, Stewart-Brown S,
Siriwanarangsan P, Fasching PA, Lux MP, Ekici AB, Beckmann MW, Peto J, Dos Santos Silva I, Fletcher O, Johnson N, Sawyer EJ, Tomlinson I, Kerin MJ, Miller N, Marme F, Schneeweiss A, Sohn C, Burwinkel B, Guénel P, Truong T, Laurent-Puig P, Menegaux F, Bojesen SE, Nordestgaard BG, Nielsen SF, Flyger H, Milne RL, Zamora MP, Arias JI, Benitez J, Neuhausen S, Anton-Culver H, Ziogas A, Dur CC, Brenner H, Müller H, Arndt V, Stegmaier C, Meindl A, Schmutzler RK, Engel C, Ditsch N, Brauch H, Brüning T, Ko YD, The GENICA Network, Nevanlinna H, Muranen TA, Aittomäki K, Blomqvist C, Matsuo K, Ito H, Iwata H, Yatabe Y, Dörk T, Helbig S, Bogdanova NV, Lindblom A, Margolin S, Mannermaa A, Kataja V, Kosma VM, Hartikainen JM, Chenevix-Trench G, kConFab Investigators, Australian Ovarian Cancer Study Group, Wu AH, Tseng CC, Van Den Berg D, Stram DO, Lambrechts D, Thienpont B, Christiaens MR, Smeets A, Chang-Claude J, Rudolph A, Seibold P, Flesch-Janys D, Radice P, Peterlongo P, Bonanni B, Bernard L, Couch FJ, Olson JE, Wang X, Purrington K, Giles GG, Severi G, Baglietto L, McLean C, Haiman CA, Henderson BE, Schumacher F, Le Marchand L, Simard J, Goldberg MS, Labrèche F, Dumont M, Teo SH, Yip CH, Phuah SY, Kristensen V, Grenaker Alnæs G, Børresen-Dale AL, Zheng W, Deming-Halverson S, Shrubsole M, Long J, Winqvist R, Pylkäs K, Jukkola-Vuorinen A, Kauppila S, Andrulis IL, Knight JA, Glendon G, Tchatchou S, Devilee P, Tollenaar RA, Seynaeve CM, García-Closas M, Figueroa J, Chanock SJ, Lissowska J, Czene K, Darabi H, Eriksson K, Hooning MJ, Martens JW, van den Ouweland AM, van Deurzen CH, Hall P, Li J, Liu J, Humphreys K, Shu XO, Lu W, Gao YT, Cai H, Cox A, Reed MW, Blot W, Signorello LB, Cai Q, Pharoah PD, Ghoussaini M, Harrington P, Tyrer J, Kang D, Choi JY, Park SK, Noh DY, Hartman M, Hui M, Lim WY, Buhari SA, Hamann U, Försti A, Rüdiger T, Ulmer HU, Jakubowska A, Lubinski J, Jaworska K, Durda K, Sangrajrang S, Gaborieau V, Brennan P, McKay J, Vachon C, Slager S, Fostira F, Pilarski R, Shen CY, Hsiung CN, Wu PE, Hou MF, Swerdlow A, Ashworth A, Orr N, Schoemaker MJ, Ponder BA, Dunning AM, Easton DF (2013) Fine-scale mapping of the FGFR2 breast cancer risk locus: putative functional variants differentially bind FOXA1 and E2F1. Am J Hum Genet 93(6): 1046-1060.

Michailidou K, Hall P, Gonzalez-Neira A, Ghoussaini M, Dennis J, Milne RL, Schmidt MK, Chang-Claude J, Bojesen SE, Bolla MK, Wang Q, Dicks E, Lee A, Turnbull C, Rahman N, Fletcher O, Peto J, Gibson L, Dos Santos Silva I, Nevanlinna H, Muranen TA, Aittomaki K, Blomqvist C, Czene K, Irwanto A, Liu J, Waisfisz Q, Meijers-Heijboer H, Adank M, van der Luijt RB, Hein R, Dahmen N, Beckman L, Meindl A, Schmutzler RK, Muller-Myhsok B, Lichtner P, Hopper JL, Southey MC, Makalic E, Schmidt DF, Uitterlinden AG, Hofman A, Hunter DJ, Chanock SJ, Vincent D, Bacot F, Tessier DC, Canisius S, Wessels LF, Haiman CA, Shah M, Luben R, Brown J, Luccarini C, Schoof N, Humphreys K, Li J, Nordestgaard BG, Nielsen SF, Flyger H, Couch FJ, Wang X, Vachon C, Stevens KN, Lambrechts D, Moisse M, Paridaens R, Christiaens MR, Rudolph A, Nickels S, Flesch-Janys D, Johnson N, Aitken Z, Aaltonen K, Heikkinen T, Broeks A, Veer LJ, van der Schoot CE, Guenel P, Truong T, Laurent-Puig P, Menegaux F, Marme F, Schneeweiss A, Sohn C, Burwinkel B, Zamora MP, Perez JI, Pita G, Alonso MR, Cox A, Brock IW, Cross SS, Reed MW, Sawyer EJ, Tomlinson I, Kerin MJ, Miller N, Henderson BE, Schumacher F, Le Marchand L, Andrulis IL, Knight JA, Glendon G, Mulligan AM, Lindblom A, Margolin S, Hooning MJ, Hollestelle A, van den Ouweland AM, Jager A, Bui QM, Stone J, Dite GS, Apicella C, Tsimiklis H, Giles GG, Severi G, Baglietto L, Fasching PA, Haeberle L, Ekici AB, Beckmann MW, Brenner H, Muller H, Arndt V, Stegmaier C, Swerdlow A, Ashworth A, Orr N, Jones M, Figueroa J, Lissowska J, Brinton L, Goldberg MS, Labreche F, Dumont M, Winqvist R, Pylkas K, Jukkola-Vuorinen A, Grip M, Brauch H, Hamann U, Bruning T, Radice P, Peterlongo P, Manoukian S, Bonanni B, Devilee P, Tollenaar RA, Seynaeve C, van Asperen CJ, Jakubowska A, Lubinski J, Jaworska K, Durda K, Mannermaa A, Kataja V, Kosma VM, Hartikainen JM, Bogdanova NV, Antonenkova NN, Dork T, Kristensen VN, Anton-Culver H, Slager S, Toland AE, Edge S, Fostira F, Kang D, Yoo KY, Noh DY, Matsuo K, Ito H, Iwata $\mathrm{H}$, Sueta A, Wu AH, Tseng CC, Van Den Berg D, Stram DO, Shu XO, Lu W, Gao YT, Cai H, Teo SH, Yip CH, Phuah SY, Cornes BK, Hartman M, Miao H, Lim WY, Sng JH, Muir K, Lophatananon A, Stewart-Brown S, Siriwanarangsan P, Shen CY, Hsiung CN, Wu PE, Ding SL, Sangrajrang S, Gaborieau V, Brennan P, McKay J, Blot WJ, Signorello LB, Cai Q, Zheng W, Deming-Halverson S, Shrubsole M, Long J, Simard J, Garcia-Closas M, Pharoah PD, Chenevix-Trench G, Dunning AM, Benitez J, Easton DF (2013) Large-scale genotyping 
identifies 41 new loci associated with breast cancer risk. Nat Genet 45: 353-361, 361. e1-e2.

Nyholt DR (2004) A simple correction for multiple testing for singlenucleotide polymorphisms in linkage disequilibrium with each other. Am J Hum Genet 74: 765-769.

Presta M, Dell'Era P, Mitola S, Moroni E, Ronca R, Rusnati M (2005) Fibroblast growth factor/fibroblast growth factor receptor system in angiogenesis. Cytokine Growth Factor Rev 16: 159-178.

Rahman N, Seal S, Thompson D, Kelly P, Renwick A, Elliott A, Reid S, Spanova K, Barfoot R, Chagtai T, Jayatilake H, McGuffog L, Hanks S, Evans DG, Eccles D, Easton DF, Stratton MR (2007) PALB2, which encodes a BRCA2-interacting protein, is a breast cancer susceptibility gene. Nat Genet 39: 165-167.

Robertson A, Hill WG (1984) Deviations from Hardy-Weinberg proportions: sampling variances and use in estimation of inbreeding coefficients. Genetics 107: 703-718.

Schwertfeger KL (2009) Fibroblast growth factors in development and cancer: insights from the mammary and prostate glands. Curr Drug Targets 10: 632-644.

Seal S, Thompson D, Renwick A, Elliott A, Kelly P, Barfoot R, Chagtai T, Jayatilake H, Ahmed M, Spanova K, North B, McGuffog L, Evans DG, Eccles D, Easton DF, Stratton MR, Rahman N (2006) Truncating mutations in the Fanconi anemia J gene BRIP1 are low-penetrance breast cancer susceptibility alleles. Nat Genet 38: 1239-1241.

Siddiq A, Couch FJ, Chen GK, Lindstrom S, Eccles D, Millikan RC, Michailidou K, Stram DO, Beckmann L, Rhie SK, Ambrosone CB, Aittomaki K, Amiano P, Apicella C, Baglietto L, Bandera EV, Beckmann MW, Berg CD, Bernstein L, Blomqvist C, Brauch H, Brinton L, Bui QM, Buring JE, Buys SS, Campa D, Carpenter JE, Chasman DI, Chang-Claude J, Chen C, Clavel-Chapelon F, Cox A, Cross SS, Czene K, Deming SL, Diasio RB, Diver WR, Dunning AM, Durcan L, Ekici AB, Fasching PA, Feigelson HS, Fejerman L, Figueroa JD, Fletcher O, Flesch-Janys D, Gaudet MM, Gerty SM, Rodriguez-Gil JL, Giles GG, van Gils CH, Godwin AK, Graham N, Greco D, Hall P, Hankinson SE, Hartmann A, Hein R, Heinz J, Hoover RN, Hopper JL, Hu JJ, Huntsman S, Ingles $\mathrm{SA}$, Irwanto A, Isaacs $\mathrm{C}$, Jacobs $\mathrm{KB}$, John $\mathrm{EM}$, Justenhoven $\mathrm{C}$, Kaaks R, Kolonel LN, Coetzee GA, Lathrop M, Le Marchand L, Lee AM, Lee IM, Lesnick T, Lichtner P, Liu J, Lund E, Makalic E, Martin NG, McLean CA, Meijers-Heijboer H, Meindl A, Miron P, Monroe KR, Montgomery GW, Muller-Myhsok B, Nickels S, Nyante SJ, Olswold C, Overvad K, Palli D, Park DJ, Palmer JR, Pathak H, Peto J, Pharoah P, Rahman N, Rivadeneira F, Schmidt DF, Schmutzler RK, Slager S, Southey MC, Stevens KN, Sinn HP, Press MF, Ross E, Riboli E, Ridker PM, Schumacher FR, Severi G, Dos Santos Silva I, Stone J, Sund M, Tapper WJ, Thun MJ, Travis RC, Turnbull C, Uitterlinden AG, Waisfisz Q, Wang X, Wang Z, Weaver J, Schulz-Wendtland R, Wilkens LR, Van Den Berg D, Zheng W, Ziegler RG, Ziv E, Nevanlinna H, Easton DF, Hunter DJ, Henderson BE, Chanock SJ, Garcia-Closas M, Kraft P, Haiman CA, Vachon CM (2012) A meta-analysis of genome-wide association studies of breast cancer identifies two novel susceptibility loci at 6q14 and 20q11. Hum Mol Genet 21: $5373-5384$.

Stacey SN, Manolescu A, Sulem P, Rafnar T, Gudmundsson J, Gudjonsson SA, Masson G, Jakobsdottir M, Thorlacius S, Helgason A, Aben KK, Strobbe LJ, Albers-Akkers MT, Swinkels DW, Henderson BE, Kolonel LN, Le Marchand L, Millastre E, Andres R, Godino J, Garcia-Prats MD, Polo E, Tres A, Mouy M, Saemundsdottir J, Backman VM, Gudmundsson L, Kristjansson K, Bergthorsson JT, Kostic J, Frigge ML, Geller F, Gudbjartsson D, Sigurdsson H, Jonsdottir T, Hrafnkelsson J, Johannsson J, Sveinsson T, Myrdal G, Grimsson HN, Jonsson T, von Holst S, Werelius B, Margolin S, Lindblom A, Mayordomo JI, Haiman CA, Kiemeney LA,
Johannsson OT, Gulcher JR, Thorsteinsdottir U, Kong A, Stefansson K (2007) Common variants on chromosomes $2 \mathrm{q} 35$ and $16 \mathrm{q} 12$ confer susceptibility to estrogen receptor-positive breast cancer. Nat Genet 39: 865-869.

Stacey SN, Manolescu A, Sulem P, Thorlacius S, Gudjonsson SA, Jonsson GF, Jakobsdottir M, Bergthorsson JT, Gudmundsson J, Aben KK, Strobbe LJ, Swinkels DW, van Engelenburg KC, Henderson BE, Kolonel LN, Le Marchand L, Millastre E, Andres R, Saez B, Lambea J, Godino J, Polo E, Tres A, Picelli S, Rantala J, Margolin S, Jonsson T, Sigurdsson H, Jonsdottir T, Hrafnkelsson J, Johannsson J, Sveinsson T, Myrdal G, Grimsson HN, Sveinsdottir SG, Alexiusdottir K, Saemundsdottir J, Sigurdsson A, Kostic J, Gudmundsson L, Kristjansson K, Masson G, Fackenthal JD, Adebamowo C, Ogundiran T, Olopade OI, Haiman CA, Lindblom A, Mayordomo JI, Kiemeney LA, Gulcher JR, Rafnar T, Thorsteinsdottir U, Johannsson OT, Kong A, Stefansson K (2008) Common variants on chromosome $5 \mathrm{p} 12$ confer susceptibility to estrogen receptor-positive breast cancer. Nat Genet 40: 703-706.

Swift M, Reitnauer PJ, Morrell D, Chase CL (1987) Breast and other cancers in families with ataxia-telangiectasia. N Engl J Med 316: 1289-1294.

The Breast Cancer Association Consortium (2006) Commonly studied single-nucleotide polymorphisms and breast cancer: results from the Breast Cancer Association Consortium. J Natl Cancer Inst 98: 1382-1396.

Thomas G, Jacobs KB, Kraft P, Yeager M, Wacholder S, Cox DG, Hankinson SE, Hutchinson A, Wang Z, Yu K, Chatterjee N, Garcia-Closas M, Gonzalez-Bosquet J, Prokunina-Olsson L, Orr N, Willett WC, Colditz GA, Ziegler RG, Berg CD, Buys SS, McCarty CA, Feigelson HS, Calle EE, Thun MJ, Diver R, Prentice R, Jackson R, Kooperberg C, Chlebowski R, Lissowska J, Peplonska B, Brinton LA, Sigurdson A, Doody M, Bhatti P, Alexander BH, Buring J, Lee IM, Vatten LJ, Hveem K, Kumle M, Hayes RB, Tucker M, Gerhard DS, Fraumeni Jr JF, Hoover RN, Chanock SJ, Hunter DJ (2009) A multistage genome-wide association study in breast cancer identifies two new risk alleles at 1p11.2 and 14q24.1 (RAD51L1). Nat Genet 41: 579-584.

Turnbull C, Ahmed S, Morrison J, Pernet D, Renwick A, Maranian M, Seal S, Ghoussaini M, Hines S, Healey CS, Hughes D, Warren-Perry M, Tapper W, Eccles D, Evans DG, Hooning M, Schutte M, van den Ouweland A, Houlston R, Ross G, Langford C, Pharoah PD, Stratton MR, Dunning AM, Rahman N, Easton DF (2010) Genome-wide association study identifies five new breast cancer susceptibility loci. Nat Genet 42: 504-507.

Udler MS, Meyer KB, Pooley KA, Karlins E, Struewing JP, Zhang J, Doody DR, MacArthur S, Tyrer J, Pharoah PD, Luben R, Bernstein L, Kolonel LN, Henderson BE, Le Marchand L, Ursin G, Press MF, Brennan P, Sangrajrang S, Gaborieau V, Odefrey F, Shen CY, Wu PE, Wang HC, Kang D, Yoo KY, Noh DY, Ahn SH, Ponder BA, Haiman CA, Malone KE, Dunning AM, Ostrander EA, Easton DF (2009) FGFR2 variants and breast cancer risk: fine-scale mapping using African American studies and analysis of chromatin conformation. Hum Mol Genet 18: 1692-1703.

Zheng W, Long J, Gao YT, Li C, Zheng Y, Xiang YB, Wen W, Levy S, Deming SL, Haines JL, Gu K, Fair AM, Cai Q, Lu W, Shu XO (2009) Genome-wide association study identifies a new breast cancer susceptibility locus at 6q25.1. Nat Genet 41: 324-328.

This work is published under the standard license to publish agreement. After 12 months the work will become freely available and the license terms will switch to a Creative Commons AttributionNonCommercial-Share Alike 3.0 Unported License.

Supplementary Information accompanies this paper on British Journal of Cancer website (http://www.nature.com/bjc) 